Article

\title{
Investigating Maturity Requirements to Operate Mobility as a Service: The Rome Case
}

\author{
Maria Vittoria Corazza ${ }^{1, *(D)}$ and Giordano Carassiti ${ }^{2}$ (D) \\ 1 Department of Civil, Building and Environmental Engineering, School of Engineering, \\ Sapienza University of Rome, 00184 Rome, Italy \\ 2 ISFORT Istituto Superiore di Formazione e Ricerca per i Trasporti, 00198 Rome, Italy; \\ giordano.carassiti@pm.me \\ * Correspondence: mariavittoria.corazza@uniroma1.it
}

Citation: Corazza, M.V.; Carassiti, G Investigating Maturity Requirements to Operate Mobility as a Service: The Rome Case. Sustainability 2021, 13, 8367. https://doi.org/10.3390/ su13158367

Academic Editors: Gonzalo Fernández-Sánchez and Rafael Cortes

Received: 21 June 2021

Accepted: 23 July 2021

Published: 27 July 2021

Publisher's Note: MDPI stays neutral with regard to jurisdictional claims in published maps and institutional affiliations.

Copyright: (C) 2021 by the authors. Licensee MDPI, Basel, Switzerland. This article is an open access article distributed under the terms and conditions of the Creative Commons Attribution (CC BY) license (https:// creativecommons.org/licenses/by/ $4.0 /)$.

\begin{abstract}
The maturity of a city to operate a Mobility as a Service (MaaS) ecosystem has been often analyzed in the literature. This and the consideration that MaaS is mostly found in areas with long-enforced transit-oriented policies and efficient multimodal supply raise the research question of whether it would be possible to operate MaaS in urban areas where mobility management is addressed according, on the contrary, to a conservative approach. A field study developed in Rome as a case in point, aimed at analyzing the actual feasibility of local MaaS operations, indicates that limitations are due to the citizens' low willingness to pay. This is originated by a general underestimation of transit costs and made harsher by the inveterate use of passenger cars as the prevailing modal choice. The paper analyzes the results achieved, collected via a questionnaire, and highlights additional barriers to implement MaaS strictly related to its social acceptance, rather than to its technical viability, as to which the city, instead, is mature. The lesson learnt is that MaaS might be operationally (or technically) feasible even in challenging contexts, like Rome's, but the prerequisite is to create supporting policies, for which a number of actions are outlined and elaborated, with the research goal to advance knowledge in this field, especially for decision-makers and potential stakeholders who might perceive MaaS as a too-demanding option for the context they operate in.
\end{abstract}

Keywords: MaaS; sustainable mobility; conservative policies

\section{Introduction}

As for many emerging concepts, Mobility as a Service (MaaS) has never stopped evolving since its initial formulation in Helsinki, Finland. Here, MaaS originated in 2014 when local administrators analyzed the possibility to reorganize the transportation supply to meet the passengers' evolving requirements generated by the new sharing and servicing opportunities [1]. Although the concept of integrated services was not unprecedented [2], the MaaS novelty relied on the mix of on-demand mobility service supplied (including both private and public modes, motorized, and non-motorized), all managed by one single body, via digital technologies (Information Technologies-IT and mobile devices) [3], to be paid through a subscription or a pay-per-trip scheme. The provision of a vast array of different solutions is the MaaS" "trademark", typically bundling transit, paratransit, and parking, thus supplying a mix of consolidated and "niche" services, from taxi to ridehailing, car rental, carsharing, etc.

After less than a decade from its launch, MaaS is acknowledged as a "new paradigm that focuses on providing a single platform for combining all the existing transportation options and provides them to the customers as an integrated and simple solution" [4] (p. 416) and its attractiveness in providing portfolios of different mobility services, made available via an app and tailored in a way to provide both conventional and door-to-door mobility options within one single payment method, is undisputed. MaaS is operated in several urban areas, mostly in Northern Europe, North America, and Australia, and is 
expanding in Asia, moving from Japan [5], with potential also observed in rural areas [6,7]. The availability of a Public-Private Partnership (PPP), i.e., the MaaS Alliance, involving the major players worldwide in order to develop a common approach, along with the vast scientific and grey literature [8-10], are further evidence of the momentum MaaS is gaining in the sustainable mobility arena.

However, although successful, MaaS is still perceived as a "niche" option in such an arena, and further research is needed if only because MaaS is still developing. More specifically, the current practice raises a basic research question: Is MaaS transferable or replicable everywhere? Or, in other words, which are the levels of maturity required for a given city to operate MaaS successfully?

This research question relies on the observations that: (i) The majority of the current MaaS operations take place in areas with well-established sustainable mobility policies and governance; (ii) the typical MaaS customers can be associated with specific social strata (specifically, the web-literates, the commuters, the millennials, [4], or more in general, medium-to-high-income users); (iii) a consolidated practice of MaaS economic sustainability (i.e., a global framework for taxation, funding, subsidies, and business models [11]) is still city-scale-based; (iv) the impacts on travel behaviors over the far horizon appear still uncertain [12]; and (v) the perception of MaaS is still a novelty. All these factors are also corroborated if research and practice around the world are considered. Said literature on MaaS abounds, thus evidencing the researchers' recurring interest in some areas: Travel behaviors or modal choices of the MaaS customer [12-14]; the way to integrate the different mobility services into specific "bundles" or packages of multimodal transport services $[2,15,16]$; the identification of general business models [17-19]; and last but not least, comparative analyses on the progress of the research itself represented by the many literature reviews $[8-10,20]$. These issues, along with others, will be further elaborated in Section 2. Practice is no less important in studying MaaS. Initially, major emphasis was placed on observing single case studies, with Finnish case studies pioneering (e.g., Helsinki [21] and Tampere [22]), and soon followed by other northern European urban areas with similar operational schemes (Amsterdam, Antwerpen [23]; West Sweden [24]). More pilots occurred elsewhere outside Europe, with operations consolidating in Sydney [25] and in the United States [26]. However, the MaaS escalation enables one to observe how practice is no longer focused on local exploitations but in creating different types of partnerships between transit operators and transportation network companies. If, initially, the goal was simply to consolidate the pilot case into long-term practice, by a MaaS operator as the main player (e.g., Whim in Helsinki or UbiGo in Gothenburg), this scheme soon enlarged with transportation network companies like Uber or taxi operators performing last-mile service and integrating the conventional transit supply [26]. Nowadays, "MaaSification" is a worldwide practice involving not only public transit operator and providers, but also national rail operators like in Switzerland, Germany, and France, tourism multiservice apps like Rome-to-Rio in Australia, and multinational car rental companies. This means that MaaS also evolves in terms of quality and complexity.

The Rome case study, described in this paper, moves from these observations, and replies to the research question on MaaS transferability, with a focus on the additional barriers generated by a demanding context. Rome seems potentially mature, as it meets most of the basic requirements to implement MaaS outlined in literature (availability of IT infrastructures, multimodal transit supply, regulations, cooperation among the transit operators, according to $[10,27,28])$; yet, local structural mobility problems, conservative mobility governance, and the uncertainties associated in implementing paratransit all highlight that operating MaaS in such conditions would need additional knowledge. Central in this is the role of the users and their willingness to use and pay for the service. The present study focuses on this, given the scarce familiarity Romans have with MaaS and their contrasting feelings towards local mobility.

The research goal is to outline such supplementary criteria for introducing MaaS in potentially mature contexts, starting from the lesson learnt in Rome, thus advancing 
knowledge in the field of MaaS operations and transferability. This will also include additional considerations emerging from the 2020 pandemic and the generated increase in the passenger cars' share, which raise issues on the sustainability of MaaS if perceived by the general public as a solution to favor solo driving.

\section{Rationale of the Paper}

The research question originates from an exploratory field study run in Rome during Fall 2020, i.e., between the pandemic first and second waves (respectively Winter-Spring 2020 and Winter 2021) and aimed at analyzing the feasibility of local MaaS operations. The scientific literature review, synthesized in Section 2, used to develop the study, helped to determine research criteria and develop the methodology to assess the feasibility of MaaS operations in Rome, elaborated in Section 3. The original results achieved are fully presented in Section 4 and commented on in Section 5, also in light of the difficulties posed by the 2020-2021 pandemic. To conclude, additional directions to assess the actual MaaS feasibility, beyond its technical viability, are proposed (Section 6), with the additional research goals of also advancing the implementation process of MaaS in sensitive cities and providing a basis for further research in this field.

\section{The Knowledge Base to Develop the Assessment Methodology}

Scientific and grey literature on MaaS abound as do the description of case studies, giving rise to a relevant strand of literature reviews (as in [8-10,15,20,29], among the many valuable ones). To develop the field study, the analysis of the scientific literature, starting with the above-mentioned sources, proved necessary to understand the principles behind MaaS and its interpretation as an ecosystem [30], shedding light on the challenges of implementing MaaS in a sensitive context like Rome's.

\subsection{MaaS as an Ecosystem: Key Issues in Scientific Literature}

Aside from the repeatedly remarked availability of a large number of definitions (none of them legally binding or univocally shared) and its potential in innovating urban mobility patterns, further MaaS elements of novelty highlighted in the literature are the user-centered approach [31,32]; the combination of paratransit, public transport, ride sourcing [33], and micromobility; and the likely positive impacts on sustainability, as also evidenced by the centrality of MaaS in several projects on sustainable mobility funded by the European Commission [34]. The acknowledgement that no MaaS would be possible without IT has also been emphasized [35]. If this, on the one hand, introduces the issue of equity due to the IT poor access and attractiveness among the web-illiterates [36], on the other, it stresses the need to also study the effects under the psychological point of view, in terms of general vision and individual perception. The former relates to how MaaS is generally promoted to the public and discussed among the experts, i.e., an innovation hyped as a mix of enthusiasm and business [35]); the latter is the individuals' feeling about the service, which might even be in contrast with such general vision, due to diminished control over daily travels, with special regards to commuting [37].

Yet, in the literature, major emphasis has been placed on "integration", which in MaaS takes place at the levels of: (i) Information; (ii) booking, ticketing, and payment; (iii) services, from planning to management and supply; and (iv) societal goals $[9,38]$. The first three levels can be included under the more general integration of IT tools, where a single digital platform enables users to have one single ticket or subscription, to be paid through a single channel, for a single bundle. The fourth level concerns the process of framing MaaS within the cities' regular policy making and governance of environmental, social, economic issues [38].

Integration is not a novelty in urban mobility. As an organizational and operational process, integration is a goal that decision makers have always strived to achieve, not only in terms of fares or information [39]. Physical integration as the design of intermodal facilities associated with the creation of seamless multimodal travel opportunities, along 
with policy integration as the univocal governance of all the issues related to transportation (thus including, for example, land use or environment planning management), have always been pillars in the approach towards more sustainable mobility patterns, well ahead of the MaaS advent [40].

With MaaS, integration evolves as a concept, with the emphasis no longer placed just on organizational processes, but on actors. The resulting scenario becomes populated by a community of players (among these, users, service providers, integrators, owners and managers of IT and physical infrastructure and fleets, decision-makers, etc.). The definition of MaaS as an ecosystem $[15,30,31,41]$ is thus consistent with all the above, as it refers to the interaction between such a community and its organizational environment. Integration also here becomes a synonym of maturity as the MaaS ecosystem relies on full cooperation among all involved parties.

It can also be argued that such community members are not new, yet their roles are. There are no more passengers, but "users" or "customers"; the public transport operator is no longer the major body in supplying mobility, but a player among others, i.e., taxi, car leasing, or rental operators; the conventional transport manager has morphed into a service broker (i.e., a "buyer" of mobility services in charge of re-selling them, bundled in a way as to meet customers' needs), somehow similar to integrators in logistics; once supporting actors, data providers and managers are now major players on par with users and transit operators, together creating the MaaS core business; eventually, new roles and areas of interest appear: Investors, media, and insurance [31].

MaaS belongs to the business and corporate cultures rather than to that of conventional public management. However, the number (or plethora) of the parties involved calls for an additional requirement, that of intermediacy, in order to manage the complexity in the interplay, up to a supra-local level, as in the case of Sweden [42].

One more point to consider is the previously mentioned MaaS positive expected impact on the environment. A number of case studies try to assess the extent of such potential, but there seems to be no actual evidence of a direct relationship between MaaS implementation and decreased air or noise pollution, energy or space consumption, or congestion. Most is assumed as a consequence in the change of travel behaviors in favor of shared or collective modes [43-45], and even more if the latter are powered by cleaner engines, with electrification having the lion's share [46]. The remark that MaaS actual effects are yet to be fully measured [47] becomes even truer when assessing its environmental sustainability.

This shifts the attention to a dimension of sustainability more frequently considered in the literature on MaaS, i.e., the economic one. Although the common assumption is that economic sustainability is not reached at the expenses of the reduction of local resources, in many studies it is implied that MaaS' economic sustainability equates to profitability (thus, perfectly aligned with the concept of mobility as a commodity, typical of urban transformations [48]). This explains the emphasis placed on describing several examples of business models and cases (mostly pilots) [49-52], or their conceptualization [17-19,35].

\subsection{Additional Considerations When Adopting MaaS in Sensitive Contexts}

All of the above expands the original research question, i.e., that of the maturity required by a target city, which relies on five dimensions: (i) Transport operators' openness and data sharing; (ii) policy, regulation, and legislation; (iii) citizens' familiarity and willingness; (iv) ICT infrastructure; and (v) transport services and infrastructure [27].

In sensitive contexts, i.e., urban areas where MaaS is exploited to innovate conservative mobility policies (characterized by monopoly in the transit management and car-dominant modal share), the above dimensions call for further considerations, in terms of:

- Level of integration already in place: As integration is the condicio sine qua non to implement MaaS, no integration certainly results in a hindrance. The availability of existing multimodal transit within a local travel planner or fare integration might not be enough [38], given the MaaS ecosystem' complexity. 
- Data sharing: Access to transport operator data can be based on a proprietary Application Programming Interface (API) if up to that moment there was no need to share, in case of just one local transport operator in charge. When granting access to the MaaS provider, the problem becomes not just technical (i.e., the right clouds and interface to share data), but also decisional (create a larger multi-proprietary API or move towards a standard-based one [53]). There could also be the need to create API standards if these are not available, in the case of the full monopoly of the transit service [31].

- Organizational transition: Conventional or conservative approaches to mobility tend to manage the transit supply within a restricted amount of bodies, thus operating under a de facto monopoly scheme (typically, one single public transport operator managing the local fleet and infrastructure, flanked by a number of minor bodies operating paratransit or other supporting services, with the latter far from reaching the lion's share). On the contrary, MaaS is associated with operational scenarios inhabited by a large number of actors [54], all playing at least a theoretically equal role, in a heterarchy scheme. This poses the question of the appropriate number of bodies to launch MaaS operations, when assessing the feasibility of the local mobility's transition from monopolistic and hierarchical to plural.

- Role of the users: In the MaaS ecosystem, passengers become customers. This implies the development of different motivations and perceptions, closer to usage habits typical of other consumption areas (such as e-commerce products and/or on demand services [55]), rather than of those usually associated with public transport. Motivations that might appear common to both MaaS and transit, like simplicity, convenience, and flexibility, are expressed in the case of MaaS in terms of product comparison [56] rather than as conventional transit perks over passenger cars. For the Maas users, the sentiment of relatedness (i.e., "the feeling to be connected to likeminded people" in [55] (p. 300)) is also more similar to that of a consumer group purchasing the same product or related to hedonic motivations [54], than to that of passengers sharing the same mode; in any case, very far from the solidarity observed in the case of ride-sourcing [57]. Consequently, the willingness to pay becomes crucial not only to assess affordability or profitability of MaaS, but also the passengers' readiness to accept it as a self-standing service rather than a complement of conventional transit and paratransit supply.

- Different mobility patterns: The transition from passengers or drivers to MaaS customers also implies different travel behaviors. Drivers opt for private cars due to the assumed personal convenience, with this implying a range of motivations (from car ownership as a status symbol to poor access to transit, to the need to travel "impromptu", fast, without depending on schedules, for any type of purposes, systematic or not, etc.). Drivers perceive travel costs as naturally associated to the vehicle's ownership, operations, and maintenance, thus assuming them as affordable. Often, drivers underestimate such costs [58], also because they perceive them as small everyday expenditures due to fuel, tolls, parking charges, either via immediate or deferred payments. Transit passengers find in riding different elements of convenience, as they often have no access to cars (due to age and income level, mainly), might find restrictions in accessing given destinations (typically city centers where Limited Traffic Zones-LTZs are enforced or parking is expensive), or are comfortable with transit operations (in terms of schedules, proximity, reliability). All of the above also meets the passengers' travel needs due to commuting and/or secondary trips for errands and shopping, visits: Arrive on time, in a reasonable timespan, in an inexpensive way. On this last point, unlike drivers, they are perfectly aware of direct travel costs as the associate them with ticket or pass fares. If, in the past, cash was the only payment methods, contactless options are gaining momentum even among the older generations. MaaS customers are different: Unlike drivers, they want to share a vehicle and not own it, and not out of necessity like some transit riders. They might have the same riders' or drivers' travel needs but to meet them they want more options (i.e., the 
service bundles) and they are willing to pay for them, because they are also aware of additional costs, the externalities due to congestion, detrimental to the community life. Eventually, unlike riders or drivers, their only option of payment is contactless, with no possibility to resort to cash. One more issue to consider would be, then, how to shape the bundle configurations: These must necessarily replicate some conventional options in the mobility patterns of drivers and riders if the goal is to turn them into MaaS customers. If MaaS appears a too disruptive innovation, the risk is to have its consolidation slowed down by conservative mobility patterns.

- Types of sustainability: Motivations to operate MaaS seem associated more with economic rather than environmental sustainability. However, in conservative environments, especially in Europe, innovations in urban mobility are very often introduced in forms of measures to mitigate externalities and, in general, to reduce the reliance on passenger cars. This might set unmet expectations, if environmental benefits are expected to be achieved over the near horizon, or cause incongruities with the regulatory tools, which postulate MaaS among the measures to reach greener mobility patterns. As to the latter, examples are the Sustainable Urban Mobility Plans, widely enforced across Europe to this end, and often encompassing MaaS as a way to increase the collective modes share [59-61].

Such additional considerations become structural factors simultaneously determinant and diriment for the case study in hand, further introduced.

\section{Reasons to Operate MaaS in Rome}

MaaS can indeed meet a number of requirements typically associated with sustainable mobility patterns. Among others, it might steer towards higher shares of collective modes in cities where the private car is the prevailing mode; its principles comply with the most advanced regulatory tools in the field of eco-friendly mobility (and in fact, it is often endorsed); it can reshape conventional and conservative mobility policies by creating plural sourcing and governance structure so as to increase the efficiency of the transport services [62]; and eventually, it can contribute to steer the increased amount of private car trips generated by the 2020-2021 pandemic toward personalized (but shared) mobility services.

The city of Rome falls in all of the above cases, and a short summary of the contemporary mobility conditions can contribute to understand the MaaS local potential.

\subsection{Contemporary Conditions}

Rome's location and form laid out more than 2700 years ago originated from a small settlement at a ford on the Tiber river, which flourished until becoming a metropolis of $1,000,000$ inhabitants during the Roman empire. This original, walled core dictated the city form until the beginning of the 1900s, when the expansion outside the city walls slowly started, progressed until World War II and escalated soon after, giving rise to suburbs and small townships, all located along the ancient Roman radial arterials. In this process, the city remained mostly mono-centric, even though masterplans promoted more central areas, all failing to match the uniqueness and the vibrancy of the historic core. As a result, today Rome is a Metropolitan area, inhabited by around 3,000,000 inhabitants, with the majority of administrative, commercial, and tourist activities located in the city center (a district of just 100,000 inhabitants). With the exception of a few pure residential areas, mixed land use is the city's characteristic functional pattern. This and the Roman network of old radial arterials still operational, along with the issue that the city was born well ahead of the car's advent, all contribute to generate congestion phenomena across the whole urban area, as Romans commute not only from/to the city center, but also inter-districts. Poor air quality, jeopardizing both citizens' health and the premium-value built environment and landmarks, is the most critical consequence of congestion.

However, it has been only since the 1970s that Rome's structural mobility problems became a city priority, as they were due not only to its ancient form as abovementioned, but also to its scarce adaptation to the mobility requirements dictated by its growth after World 
War II. The 2019 motorization index of 0.91 (the number of vehicles/number of inhabitants, excluding infant and senior population, including Powered Two-Wheelers -PTWs) is evidence of the consequences of the massive motorization in the past. Moreover, only $35 \%$ of the registered passenger cars are compliant with EURO V and VI standards [63,64]. At the same time, the transit supply managed by the local utility company still nowadays presents serious management problems; a 2286-km bus network (with a coverage index of $1.78 \mathrm{~km} / \mathrm{km}^{2}$ [64]) and a 60-km underground metro one (18 km driverless operated) result in a relatively modest production $\left(161.1 \times 10^{6}\right.$ vehkm vs. a planned one of $185 \times 10^{6}$ vehkm, in 2019 [64]). This is mostly due to poor maintenance (just around $60 \%$ of the transit fleet operates daily [64], with 28 buses catching fire during 2020 [65]) and frequent driving-staff strikes. Low customer satisfaction with a positive assessment of just around $40 \%$ for the bus service, over the 2017-2019 period [66], is not surprising. Although mitigated by the effects of the 2020-2021 pandemic, poor air quality is also an issue, and so is road safety, especially affecting vulnerable road users and PTW riders, with unaffordable social costs for the community $[67,68]$. More facts on the city mobility patterns are resumed in Table 1.

All this was originated by long-lacking comprehensive transport policies leading to deteriorated mobility conditions, with the already-mentioned massive private motorization generating intensified congestion, a decline in public transport, and neglect of pedestrians [69]. The resulting unbalanced share in favor of private cars $(50 \%$ in peak time, according to [64]) worsened during the 2020-2012 pandemic, with an additional dramatic decrease of the transit demand (well beyond the winter 2020 lockdown), and a corresponding escalation of trips by private cars, initially triggered by the public's fear of the spread on collective modes. This propensity towards "solo" travels has been complemented by the flourishing rental market of electric PTWs, largely preferred to transit by the youngest [70].

The booming of electric PTW rentals is the latest step toward the integration of the conventional transit supply with paratransit, started in the early 2000s. At that time, the municipality enforced a push-and-pull transportation policy, with main incentives to attract passengers to collective modes represented by new transit lines operated by trolleybuses and minibuses. This was complemented by additional experimental services such as car-sharing, car-pooling, and taxi-buses [71]. After a few years, bike-sharing was launched too, without much success due to poor management, and only car-sharing progressively thrived until nowadays [72], with three private companies operating free-float services and the municipal operator supplying a station-based one. Bike sharing was recently revamped, along with other sharing and micromobility services like PTWs and electric kick-scooters, the latter much appreciated, as mentioned. This results in a constellation of around a dozen different operators.

Table 1. Key mobility figures in Rome.

\begin{tabular}{|c|c|c|}
\hline & eatures & Source \\
\hline Population (inh) & $2,820,219$ & [73] \\
\hline Area (sqkm) & 1287 & \multirow{2}{*}{ [63] } \\
\hline Density (inh/sqkm) & 2191 & \\
\hline Registered fleet (veh) & $\begin{array}{l}1,771,969 \text { pass.cars } \\
393,787 \text { PTWs } \\
7671 \text { buses and coaches } \\
168,947 \text { others } \\
2,342,374 \text { total }\end{array}$ & [74] \\
\hline Registered electric modes (veh) & 13,133 & [63] \\
\hline Car sharing fleet (veh) & 2300 & \multirow{2}{*}{ [64] } \\
\hline Motorization rate ([veh/inh] $* 1000)$ & 830 & \\
\hline Modal share (\%) & $\begin{array}{l}60 \text { pass.cars } \\
20 \text { transit } \\
18 \text { walking } \\
2 \text { bike }\end{array}$ & [75] \\
\hline
\end{tabular}


Table 1. Cont.

\begin{tabular}{|c|c|c|}
\hline \multicolumn{2}{|c|}{ Urban Features } & Source \\
\hline Travel time (min) & 41.4 & \multirow{2}{*}{ [76] } \\
\hline Congestion level (\%) & 38 & \\
\hline Pedestrianized areas (sqm) & 393,277 & \multirow{8}{*}{ [63] } \\
\hline Bike network (km) & 230 & \\
\hline Peak daily access to the central LTZs (veh) & 120,000 & \\
\hline Transit—bus fleet (veh.) & 2244 & \\
\hline Transit-bus network $(\mathrm{km})$ & 4711 & \\
\hline Average bus route length $(\mathrm{km})$ & 12.8 & \\
\hline Average bus travel time (m) & 41.5 & \\
\hline Bus commercial speed $(\mathrm{km} / \mathrm{h})$ & 16.9 & \\
\hline Bus network density (route km/network km) & 3.61 & \multirow{10}{*}{ [64] } \\
\hline Electric kick-scooter fleet, estimated (veh) & 3000 & \\
\hline Park\&Ride supply (parking lot) & 14,958 & \\
\hline Pay-for-parking, on-street supply (parking lot) & 74,134 & \\
\hline Average daily trips (unit) & $5,900,000$ & \\
\hline Population daily traveling $(\%)$ & 98 & \\
\hline Average trip per capita (trip/inh) & 2.37 & \\
\hline Travel types (\%) & $\begin{array}{l}21 \text { systematic } \\
35 \text { non systematic }\end{array}$ & \\
\hline Multimodal trips ([private + public modes] $* 1000$ ) & 80 & \\
\hline Average travel time (min) & $<30$ & \\
\hline Built-up area per capita (sqm/inh) & 108 & \multirow[b]{2}{*}{ [77] } \\
\hline $\begin{array}{l}\text { Land use efficiency (Ratio of land consumption growth } \\
\text { rate to population growth rate, 10-year basis) }\end{array}$ & 3.6 & \\
\hline
\end{tabular}

\subsection{MaaS Potential in Rome: Introductory Remarks}

Romans seem to appreciate both paratransit and micromobility, although still being "niche" and unconsolidated, as effective alternatives to private cars and compensatory measures for the unsatisfactory transit supply. To this aim, any action to support a combination of travel modes where the collective part (transit, paratransit, micromobility) and walking prevail over passenger cars could really result in a more balanced modal share.

With this in mind and banking on its integration potential, MaaS could be exploited in the renewal of the local conservative governance as well as in the shift towards more advanced mobility policies based on plural sourcing and heterarchy. More specifically, in terms of organizational transition (as pointed out in Section 2.2), MaaS could be saluted for its potential in clustering and structuring all different transit, paratransit, and micromobility companies in order to promote plural operations, with transit serving the central leg and the latter two the first or last miles of everyday journeys.

At the same time, in the present scenario, where traffic has again reached the prepandemic levels and transit demand is still lagging behind [78], MaaS can be exploited with the long-term goal to shift the local demand from private to collective modes, combining its potential to attract customers to paratransit and micromobility with the citizens ${ }^{\prime}$ current propensity towards both. This approach could be the instrument most suitable to achieve the desired sustainability goals, thus addressing the issue of sustainability raised in Section 2.2.

Two more conditions might support the introduction of MaaS in Rome. First, under the regulatory point of view, MaaS is part of the local Sustainable Urban Mobility Plan vision, enforcing the implementation of a web platform, managed by the Municipality, specifically designed to integrate operations [63]. This and the fact that MaaS is strongly 
supported by the national regulation on sustainable mobility is consistent with the highest level of integration, that of societal goals [38], previously mentioned.

Secondly, the local availability of apps (like Moovit) and web platforms (like MyCicero) meets the requirements of the lower levels of integration, i.e., those concerning planning/service, and ticketing/payment [38]. One more integration option in the field of payment and ticketing (called Metrebus) is provided by the transit operator, in the form of a multimodal transit pass for the whole network and Park and Ride facilities across the metropolitan area. The availability of such tools partly responds to the issue raised in Section 2.2 about the level of integration already in place, and their technological maturity could enable to process paratransit and micromobility operations.

On paper, typical MaaS features like endorsing regulations, different levels of integration, multimodal supply combining transit, paratransit, and micromobility, are all available in Rome. Transit monopolistic management, a conservative mobility policy, and citizens' poor satisfaction with public transport services may also play an important role in favoring change and innovation. However, the interest of citizens in passing from passengers or drivers to MaaS customers is still largely unexplored, calling for a specific study on their actual willingness to change.

\section{The Methodology Adopted}

The need for additional investigation on what makes people choose sustainable modes of transport over private cars, specifically for the Rome case, has been already highlighted [79]. It becomes crucial if the goal is to assess whether MaaS can really contribute to that. As stressed in Section 3, under the organizational, operational, and regulatory points of view, the MaaS implementation, although demanding, would theoretically be possible. In fact, it could represent a driver for change, as further discussed. This leaves the identification of the eligible users as the core of the analysis to assess the actual MaaS feasibility. The circumstance that, thus far, MaaS is virtually unknown among Romans calls for a direct investigation.

To this end, a multistep methodology was developed (Figure 1), starting with the initial literature review, in order to outline drivers and barriers; its results have been synthesized in Sections 2 and 3.

This was the basis to design a survey in order to profile potential customers and identify their travel behaviors, requirements, and willingness to pay. Question formulation was based on previous research focused on highlighting the pros and cons of innovative transport systems $[46,80]$.

The following data process was two-pronged: On the one hand, it created a sound statistical basis to assess the economic viability of the service bundles revealed by the interviewees, according to a general business model scheme; on the other, it outlined possible criteria for the MaaS implementation in Rome.

\subsection{The Survey Design and Development}

As mentioned, Romans are not familiar with MaaS, thus its introduction and feasibility can be only assessed by crowdsourcing. A specific questionnaire was developed to assess: (i) Potential bundles; (ii) the interviewees' willingness to pay for them; (iii) usual travel behaviors; (iv) further elements of the attractiveness of the service; and (v) the level of environmental consciousness among the respondents, as an additional driver to implement MaaS in Rome. This last issue was prompted not just by the centrality of environmental friendliness in any analysis on urban mobility, but also by some contrasting feelings among the Romans, following the enforcement of the push-and-pull transportation policy mentioned in Section 3.1. At that time, the disincentives to use private cars were not assessed positively, even though the measured environmental benefits were evident, and some incentives like the newly launched electric minibus lines were appreciated more because of the perceived, enhanced on-board comfort rather than for their cleaner performance [71]. 


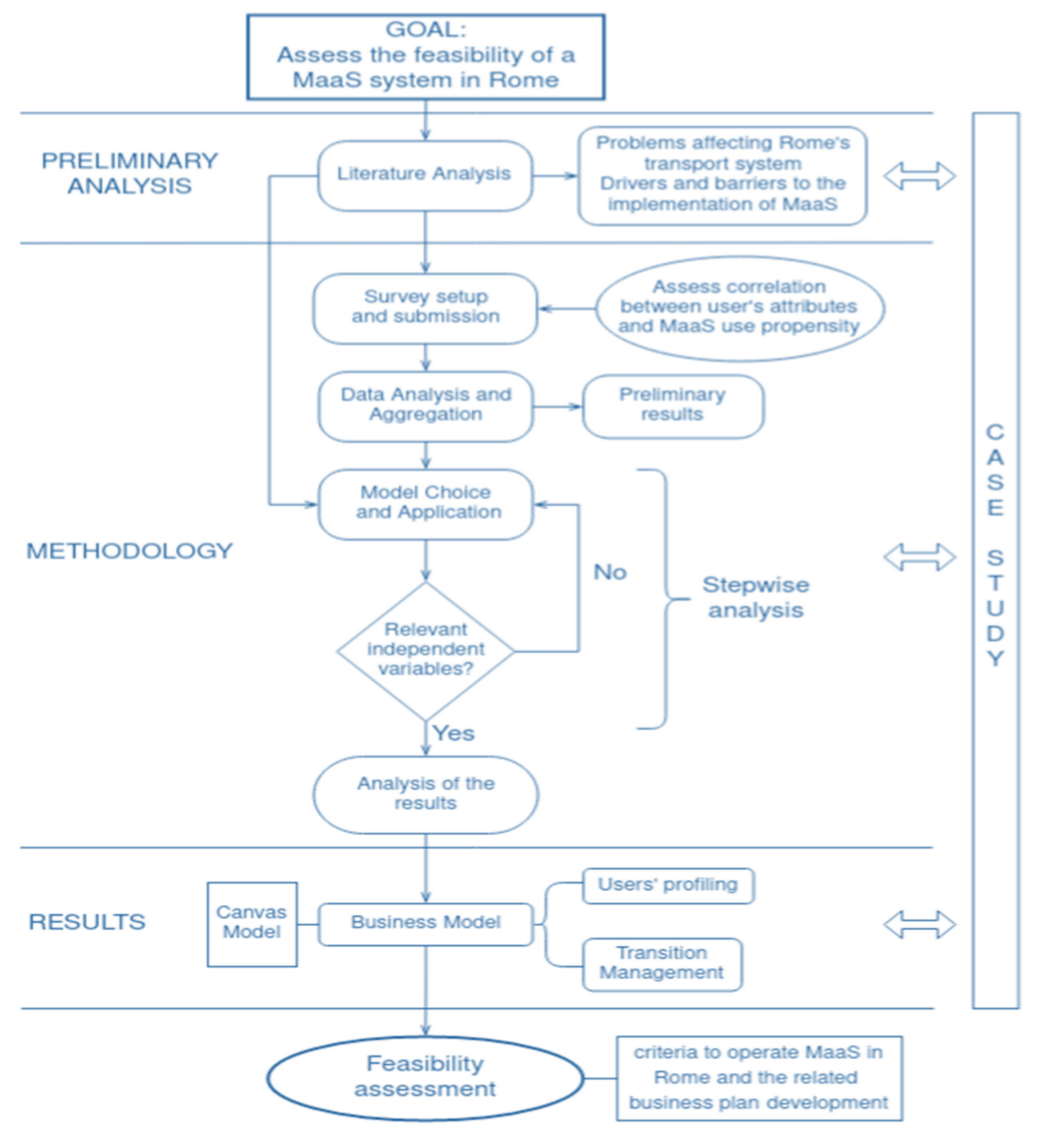

Figure 1. The adopted methodology.

The questionnaire was launched in 2020 via social media (by both social networking services like LinkedIn, Facebook, and Reddit and messaging apps like WhatsApp and Telegram). Multiple-choice responses were possible, in order to collect the largest possible set of information.

The sampling method for the survey was conventional. The opportunity to disseminate the questionnaire via social media affected the first step, i.e., the definition of the target "population", which had to be consistent with the typical MaaS customership highlighted in the literature (young, web-literate, interested in commuting [4]). This led to a process very similar to convenience sampling, because of the strengths of this option (less expensive and faster [81]). As further explained in Section 4.1.2, the total amount of respondents gave rise to two major groups (students and employees) with many similarities; moreover, all respondents duly filled in the questionnaire, which led to the decision to have the whole set of respondents coinciding with the actual sample analyzed and process all the associated data.

\subsubsection{The Questionnaire}

The questionnaire was designed to have respondents creating their own ideal MaaS operations. To this end, it was divided into two parts: A general section to profile respondents according to the usual socio-demographic features; and a specific one focusing on the MaaS bundles, according to a Stated Preference (SP) approach, already implemented in similar case studies [82-86]. A brief explanation of the MaaS concept was also provided at the beginning of the questionnaire.

In the general section, along with age, gender, income, employment, and car ownership, respondents were required to state their travel behaviors for systematic and nonsystematic trips by revealing modal choice, travel distance and duration, origin and destinations according to ZIP codes, and changes due to the pandemic. To better understand 
their willingness to pay, they were also required to disclose annual gas and insurance expenditures for the household car. Eventually, eco-friendliness was tested by asking about the interest in purchasing a new electric or hybrid car or wrecking the old one (not just because of the availability of national subsidies to rejuvenate private fleets, but to assess the "feeling of attachment" to cars), and the personal environmental sensitiveness. In the section focusing on MaaS, respondents were asked to:

- State their familiarity with the local mobility options (transit, paratransit, and micromobility) and the weekly frequency of use;

- $\quad$ Build their own ideal MaaS bundle, by combining all transit modes operating in Rome (bus, tram, and regional rail), pay parking options (Park and Ride and on-street), and paratransit and micromobility (car/bike/scooter-sharing, taxi, and ride-hailing, the latter in Italy commonly referred to as "NCC"). The decision to focus only on modes already operational was taken to avoid "dream" scenarios including well-known options (such as Uber and the like), yet currently unregulated and, thus, not feasible.

- Disclose their willingness to pay for the chosen bundle, by opting for a range of monthly rates (from 30 up to more than 50 Euros, with 35 Euros as a reference value corresponding to the monthly pass for unlimited ridership across the transit network);

- Express interest in bonuses to be possibly granted with the selected bundle. The multiple choice was among cashback (the national cashback policy having being launched in that period); free home deliveries (considering the increased demand for these services during the pandemic); free tickets to entertainment (movies, theaters, museums, and the like); discounts for the electric vehicles' charging fees; and eventually free access to the nighttime LTZs in the city center (currently one of the perks of the car-sharing services, along with free parking, access to the daytime LTZs, and use of bus lanes).

The questionnaire was structured in a way so as to have responses consistent with both pre-pandemic and "new normal" scenarios, the submission period being between the two severest pandemic waves of Fall 2020 and Winter 2020-2021. The goal was also to assess the possibility of taking further advantage of the micromobility success, following the first pandemic wave, as a "plus" in the MaaS bundles.

\subsubsection{The Data Process}

A total of 435 respondents took part in the survey, in line with the samples in literature [83-86], with a full response rate. Once collected, the questionnaire data were first processed through spreadsheet calculations and pivot functions. Data were also graphically analyzed, creating hierarchy or "preference" trees, as in Figure 2, where an example based on the respondents' first modal choice for the bundle is shown.

Due to the high amount of responses' variables to be analyzed and the resulting choices observations, data were further processed by a data-analysis software, within a Multinomial Logit Model (MLM), through a Forward Stepwise Method (FSM). The MLM regression as in (1):

$$
\log \left(\frac{\pi_{j}}{\pi_{J}}\right), \text { for } j=1,2, \ldots, J-1
$$

is based on logit probabilities of responses for $(J-1)$ non redundant pairs of categories, where $\pi_{\mathrm{j}}$ and $\pi_{\mathrm{J}}$ are the probabilities associated each $j$ and $J$ categories, respectively (with $j$, $J$ as variables corresponding to the option choices for each survey question).

Each $J$-category is processed as a reference category. In the regression, it is possible to observe how each predictor affects each category of dependent variables, compared to the considered $J$ reference category, as in the following function (2):

$$
f(j)=\log i t\left(\pi_{j}\right)=\log \left(\frac{\pi_{j}}{\pi_{J}}\right)=\beta_{0, j}+\beta_{1, j} * x_{1, i}+\ldots+\beta_{j} * x_{M, i}
$$


where $\beta$ represents each variable category's influence in predicting the independent variable's outcomes and $x_{j}$ is a proxy variable for each independent variable category, within the $M$-set of observed variables.

The function (2) correlates the $M$-set of observed variables (represented by the " $x$ predictors") to their specific $\beta$-parameters, to describe the probability of the dependent variable having $j$ as an outcome and given the predictors' $i$-observation.

The independent variables considered were: (i) Respondent's features; (ii) driving license and car ownership, and related expenditures; (iii) awareness and knowledge of the electric and shared services; (iv) trips characteristics; and (v) perception of public transport and related expenditures.

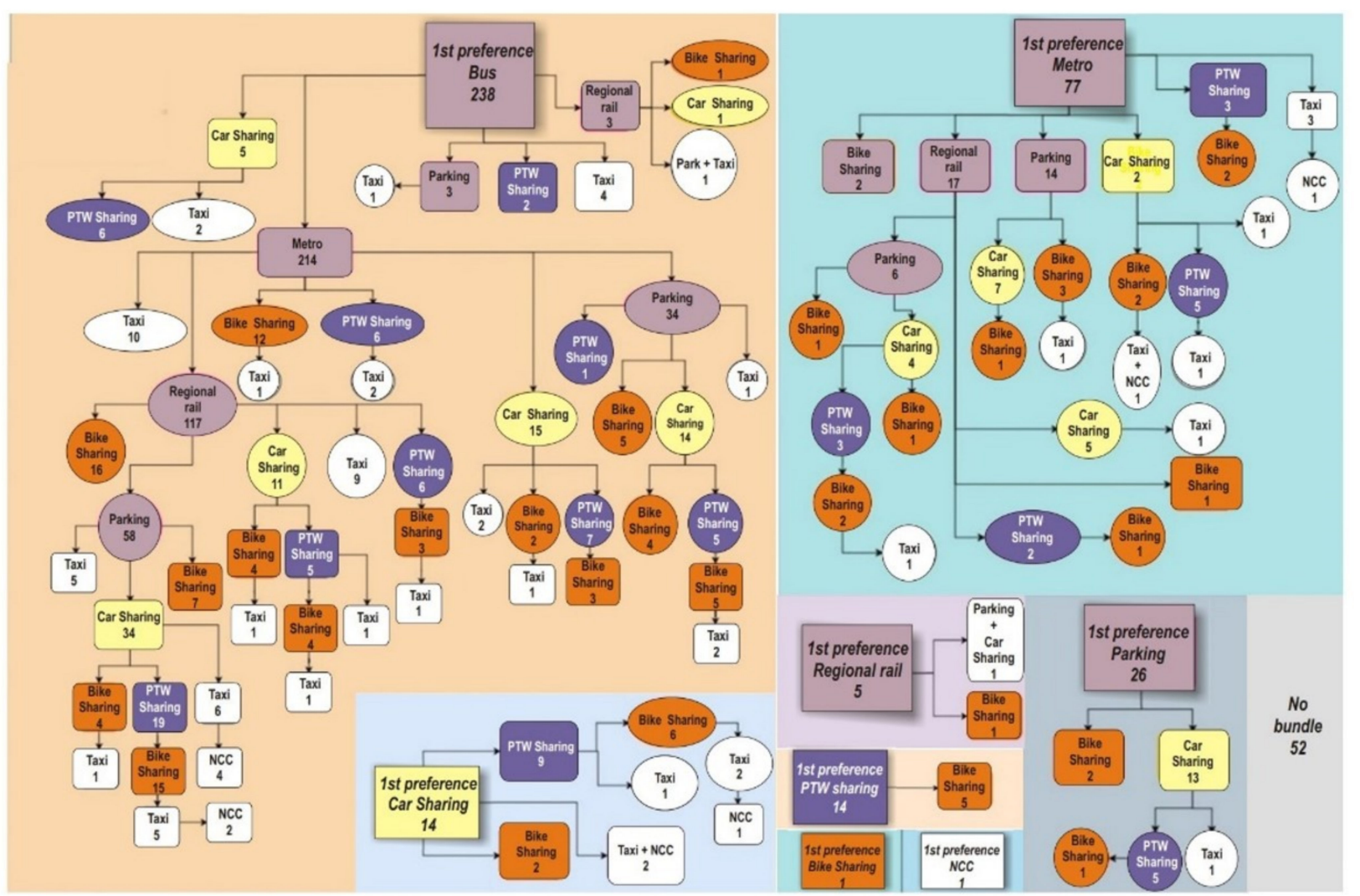

Figure 2. The "preference tree", an example.

For example, a MaaS bundle option is the dependent variable, whereas independent variables are correlated to each question (i.e., "travel purpose" question is associated with three options: $j_{1}$ "work", $j_{2}$ "study", $J$ "other", with $J$ as reference category). The model provides $x$-predictors with 1 or 0 values, depending on whether the category is considered or not. When the predictor equates to 1 (i.e., is "active") $\beta$-values represent each predictor's influence (positive or negative) on the dependent variable. In the FSM, the regression was processed by the data analysis software; in the iteration, a new independent variable was added at each run and the results analyzed, until the simulation's completion.

\subsection{The Operational Feasibility as a Requisite to Create the Right Implementation Scenario}

The results from the SP analyses and simulations were used as a basis to further assess the operational feasibility through a Business Model Canvas (BMC), with the final goal to identify the service main characteristics, possible customer groups, and, eventually, the most suitable cost-revenue scheme [52].

The use of BMC, a well-known tool with a large number of applications since its initial formulation [87], again poses the question of the appropriate selection of stakeholders to 
populate the MaaS ecosystem and more specifically that of the MaaS Service Provider. This actor is in charge of developing and running the ecosystem according to three scenarios: (i) Market-driven; (ii) public-driven, and (iii) as a cooperation between the previous two, under the form of a Private-Public Partnership (PPP) [38,88], with an expected share of expenditures and risks as a major benefit. Each scenario gives rise to specific policy directions to operate MaaS, with different roles for the public or private bodies involved. It is rather intuitive that in a market-driven scenario, private players in charge of developing a local MaaS might have operational efficiency and profitability as business targets, leaving to the public entity the task to control and/or subsidize operations, at least in the inception phase. In contrast, within a public-driven scheme, public administrators might set the MaaS appropriate operational and economic conditions, consistently with the local mobility policies, based on societal targets like equity or inclusion, and leaving to the private bodies the service management. Less investigated is the PPP potential as, in the literature, it is mostly referred to as rural MaaS pilot cases [89] or as a recommendation [61,90].

For the Rome case, the identification of the right scenario becomes a crucial parameter, as this is the frame in which the transition from the conservative mobility conditions, described in Section 3.1, might take place.

\section{The Achieved Results}

The methodology described above enabled us to achieve quantitative results from the SP data process, so as to identify the MaaS' main characteristics that the potential demand would like to be implemented in Rome. More specifically, SP data provide clear indications on the possible MaaS bundles, thus highlighting whether the demand is aware of the MaaS potential and the willingness to pay for it, as fully described in Section 5.1. The survey results and the BMC study also provided a basis to profile potential customer groups and outline the right implementation conditions, as described in Section 5.2.

\subsection{Understanding MaaS Potential: Users and Choices}

The survey results can be divided in two parts: A first one describing the respondents' features and travel habits; and a second one reporting their desires as possible MaaS customers (i.e., the "MaaS confidence"). In the survey design, the first part was conceived as a reference for the interpretation of the outcomes from the second part, as outlined in the next two sections.

\subsubsection{A Respondents' Snapshot}

The respondents' snapshot is that of young individuals ( $60 \%$ under 35 years of age). Around $40 \%$ of them are students, and $46 \%$ are employed with very different incomes (one-third stating a yearly amount between 25,000 and 50,000 Euros, another third less than 25,000 Euros). Given the questionnaire availability via social media, such major participation of young people was expected, as was the high rate of car ownership: Only $28.7 \%$ of the respondents stated no access to a private car, with travel purposes mostly related to study and work (Table 2).

Travel patterns are rather simple, with trips typically lasting up to $40 \mathrm{~min}$, with no or just one modal change. The questions about the typical origins and destinations describe a daily commute to the central areas of the city (with the historic city center represented by the black dot in Figure 3, left) and the southern business district (the so-called EUR area, the largest in orange in Figure 3, right). This and the stated travel times confirm that private vehicles (cars and PTW) prevail over transit, in the everyday modal share.

In the daily commute, $66 \%$ of the respondents (both car drivers and bus riders) state that travel time is important; however, for the transit passengers, punctuality (53\%), comfort $(35 \%)$, cost $(30 \%)$, and waiting times at bus stops (26\%) are also relevant. The low figures for comfort or waiting times are not surprising, considering the not satisfactory assessment of the local transit service by both the citizens [91] and the municipal agency in charge of controlling the public services in the city [92], and can be interpreted as the result of more 
and more adaptive behaviors to poor quality services among the citizens. The monthly travel expenditure for public transport is consistent with all of the above. On the one hand, $35.9 \%$ of the respondents spends up to 35 Euros monthly to ride across the city, which corresponds to the cost of the monthly pass (an educated guess would be that these respondents are regular pass-holders). On the other hand, $54.2 \%$ of the interviewees spend monthly less than 10 Euros, meaning that they may be either regular drivers or ticket offenders (a long-lamented problem in Rome).

Table 2. Descriptive statistics of responses on travel behaviors and patterns.

\begin{tabular}{|c|c|c|}
\hline \multirow{2}{*}{ Questions } & \multicolumn{2}{|c|}{ Responses } \\
\hline & Options & Share $(\%)$ \\
\hline \multirow{3}{*}{ Vehicle ownership } & No & 28.7 \\
\hline & Yes, car/motorcycle & 64.4 \\
\hline & Yes, moped/bike & 6.90 \\
\hline \multirow{2}{*}{ Use of electric vehicles } & Yes & 43.0 \\
\hline & No & 57.0 \\
\hline \multirow{4}{*}{ Weekly travel frequency } & 1-2 times & 16.1 \\
\hline & 3-4 times & 25.3 \\
\hline & $5-6$ times & 26.9 \\
\hline & 7 times or more & 31.7 \\
\hline \multirow{5}{*}{ Travel purpose } & Work & 42.3 \\
\hline & Study & 25.5 \\
\hline & Family visit & 0.7 \\
\hline & Shopping & 5.8 \\
\hline & Other & 24.8 \\
\hline \multirow{5}{*}{ Travel time } & $\mathrm{Up}$ to $10 \mathrm{~min}$ & 3.7 \\
\hline & $10-20 \mathrm{~min}$ & 19.3 \\
\hline & $20-40 \mathrm{~min}$ & 43.4 \\
\hline & $40-60 \mathrm{~min}$ & 20.2 \\
\hline & More than $60 \mathrm{~min}$ & 13.3 \\
\hline \multirow{3}{*}{ Intermodal changes per single trip } & 0 & 53.3 \\
\hline & 1 & 20.7 \\
\hline & 2 or more & 26.0 \\
\hline \multirow{8}{*}{$\begin{array}{l}\text { Modal share } \\
(\text { pre-pandemic) }\end{array}$} & Walking & 27.8 \\
\hline & Private car (as driver) & 44.3 \\
\hline & Private car (as passenger) & 10.6 \\
\hline & Micromobility & 8.9 \\
\hline & Public transport & 57.1 \\
\hline & Taxi & 5.7 \\
\hline & PTW & 11.0 \\
\hline & Paratransit & 9.9 \\
\hline \multirow{5}{*}{ Monthly travel expenditure for public transport } & $0 €$ & 34.9 \\
\hline & Up to $10 €$ & 19.3 \\
\hline & $11-35 €$ & 35.9 \\
\hline & $35-50 €$ & 6.7 \\
\hline & More than $50 €$ & 3.2 \\
\hline
\end{tabular}

a multiple choice.

A very last point regards the environmental concerns: Just $15 \%$ of the respondents state having none; at the same time, $20 \%$ of the respondents are not interested in electric propulsion.

\subsubsection{The Respondents' Ideal MaaS Bundles}

The results from the responses stating the "MaaS receptiveness" are reported in Table 3.

A first apparently contrasting result comes from the observation that half of the interviewees are paratransit users, but when creating the ideal MaaS bundles, only one out of three would include paratransit, and just one out of five would include taxi services and ride hailing. On the contrary, the most favored ideal mix would combine transit and parking. 

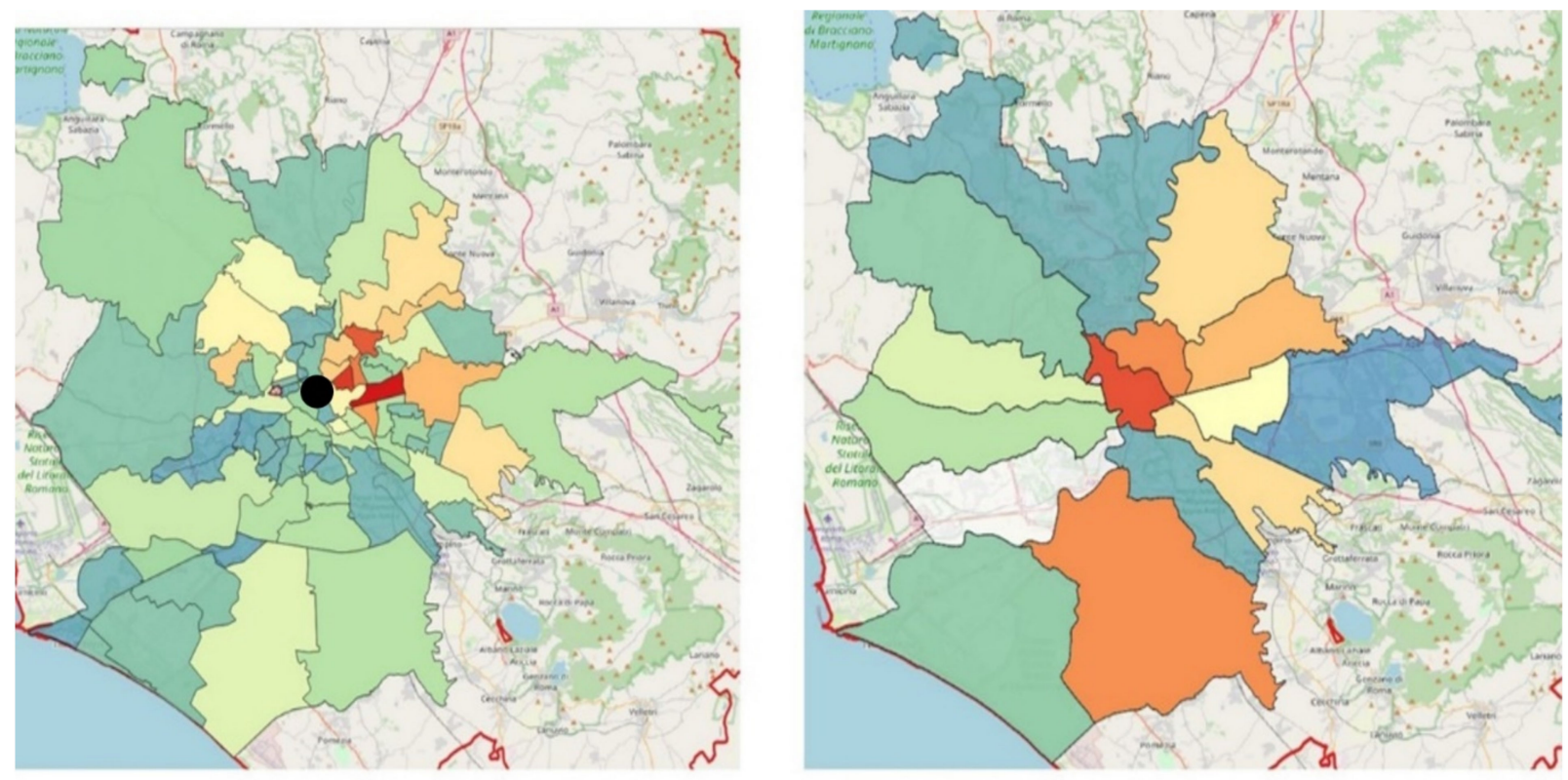

Figure 3. Origins (left) and destinations (right) in the daily commute (from orange to red, the most recurring ones; from green to blue, the least recurring ones).

Table 3. Response on the "MaaS receptiveness".

\begin{tabular}{llc}
\hline \multirow{2}{*}{ Questions } & \multicolumn{2}{c}{ Responses } \\
\cline { 2 - 3 } & \multicolumn{1}{c}{ Options } & Share (\%) \\
\hline Use of paratransit & Yes & 49.7 \\
(sharing services) & No & 50.3 \\
\hline & Bus & 54.7 \\
& Metro & 66.9 \\
MaaS bundle & Rail & 32.6 \\
(what respondents would pay for, in the travel plan) $)^{\text {a }}$ & Parking & 32.9 \\
& Car-sharing & 33.3 \\
& Moped-Sharing & 20.9 \\
& Bike-sharing & 28.5 \\
& Ride hailing & 20.7 \\
& Not interested & 12.0 \\
\hline Willingness to pay (monthly charge) & Less than 30 $€$ & 38.6 \\
& Less than 50 $€$ & 36.6 \\
& More than 50 $€$ & 9.2 \\
& Not interested in the plan & 15.7 \\
\hline Bonuses a & Cashback & 37.5 \\
& Tickets to entertainment & 53.6 \\
& Free home deliveries & 23.2 \\
& Discount for recharging electric vehicles & 21.6 \\
& Free access to the night LTZ & 16.1 \\
& Not interested in bonuses & 0.9 \\
\hline
\end{tabular}

a multiple choice.

The willingness to pay preferences are consistent with the centrality of transit observed in the bundles' creation. Only $9.2 \%$ of the respondents are willing to pay more than 50 Euros, and 36\% less than 50 Euros, whereas the majority (38\%) would pay for the MaaS subscription even less than the cost of the monthly transit pass currently available, i.e., 35 Euros. A small percentage of interviewees (15\%) is not interested in subscribing and would likely opt for a pay-as-you-go solution. This can be interpreted in different ways: Either it could be linked to those $15.4 \%$ who have no private car (probably performing no systematic trips); or it could be because they are fully relying on their own car for every travel need. 
Eventually, it is interesting to observe how most favored bonuses (cashback and tickets to entertainment) are not related to mobility services, but are perceived as gratuities or benefits, in line with the perception of MaaS as a commercial service.

\subsubsection{A Focus on the MaaS Bundles and the Related Willingness to Pay}

The interpretation of the above-presented results will be elaborated and commented in the next Section 6 but, prior to that, it is worth to report results from the MLM correlations on the MaaS bundles and the willingness to pay.

Concerning the Maas bundles, possible patterns were investigated by aggregating the observed choices in three groups:

a. Conventional behavior: A bundle replicating the transit supply (i.e., the Metrebus pass across the whole network), but extending the parking option from the currently included Park and Ride to the on-street one.

b. MaaS-friendly behavior: Monthly subscription including transit, paratransit, and micromobility services.

c. Assumed-convenience behavior: A monthly subscription including paratransit and micromobility services, which should meet a demand composed by drivers (with no whatsoever type of transit pass), using either micromobility or paratransit when convenient. This group also includes those who should opt for the pay-as-yougo scheme.

The model was run by comparing groups $a$ and $b$ with that corresponding to behavior $c$ as reference. Group $c$ has relevance not just because it can represent a typical "transitunfriendly" behavior, but also in light of the circumstance that the local carsharing (either free-float or station-based) and micromobility services are supplied only in the central areas of the city, thus excluding all peripheral sections in the green areas in Figure 3. Option $c$, thus, may represent paratransit and micromobility customers who move within the most central areas and have no interest in travelling longer distances (by local rail or metro, for example), as well as those frequently driving in the outskirts.

According to these three aggregated patterns, the model was run by selecting five independent variables reported in Table 4, i.e., (i) travel purpose; (ii) number of changes; (iii) used mode; (iv) already electric vehicles' user; and (v) already paratransit and micromobility user.

In the study of predictors, if referring to Equation (2), the "number of changes" listed in Table 3, as an example, can be considered a predictor $x$, with the " 1 change" as the option positively affecting the given bundle.

Binary variables were considered continuous (covariates), thus having results for each variable equal to the category "Yes" with respect to "No". Still referring to Equation (2) (and reminding that $\beta$-value corresponds to each variable category's influence in predicting a given independent variable's outcomes), the significance of each predictor's $\beta$-value is rendered by the model via a $\sigma$-value, which assesses the statistical validity of the given $\beta$-value. In other words, the variable is quantitatively significant if $\sigma$ is lower than 0.05 , but a higher significance is achieved when $\sigma$ is smaller than 0.01 . Thus, $\beta$-values that can be considered as significant are highlighted in yellow in Table 4 . When $\beta=0$ (blank cells in Table 3), the related category is taken as a reference for the analysis of a given predictor, is thus considered redundant by the model, and therefore ignored.

As a result, it can be observed, for instance, how a student $(\beta=1.045)$, already a transit passenger $(\beta=1.043)$, commuting with one modal change $(\beta=0.849)$ could be a MaaS friend, as attracted by bundle " $b$ " (any Transit, Paratransit, and Micromobility service); but $\beta$-values for the two variable on travel reason (study) and number or change (just 1) can also lead to bundle "a" (transit only), thus stressing that conventional behaviors are still relevant (Table 4 ).

The same type of analysis was applied to the willingness to pay (Table 5), considering the following three groups:

a. MaaS-unfriendly: Willingness to pay less than 30 Euros; 
b. MaaS-supporter: Willingness to pay less than 50 Euros

c. MaaS potential customer: Willingness to pay more than 50 Euros.

Table 4. Predictors for bundle types, correlations.

\begin{tabular}{|c|c|c|}
\hline Bundle Type ${ }^{a}$ & Variables & $\beta$ \\
\hline \multirow{11}{*}{$\begin{array}{l}\text { (a) Transit only } \\
\text { (conventional) }\end{array}$} & Travel purpose $=$ Work & -0.137 \\
\hline & Travel purpose $=$ Study & 0.469 \\
\hline & Travel purpose $=$ Other & \\
\hline & N. Changes $=1$ & $1.359 *$ \\
\hline & N. Changes $=2$ & 0.703 \\
\hline & N. Changes $=0$ & \\
\hline & Mode used, pre-pandemic $=$ Public and Private & $0.879 * *$ \\
\hline & Mode used, pre-pandemic $=$ Public & $1.333 *$ \\
\hline & Mode used, pre-pandemic $=$ Private & \\
\hline & Previous use of electric vehicles $=$ Yes & $-0.839 * *$ \\
\hline & $\begin{array}{l}\text { Previous use of paratransit and micromobility } \\
\text { Services = Yes }\end{array}$ & -1.096 * \\
\hline \multirow{11}{*}{$\begin{array}{l}\text { (b) Transit, Paratransit and } \\
\text { Micromobility } \\
\text { (MaaS-friendly) }\end{array}$} & Travel purpose $=$ Work & 0.462 \\
\hline & Travel purpose $=$ Study & $1.045^{*}$ \\
\hline & Travel purpose $=$ Other & \\
\hline & N. Changes $=1$ & $0.849^{* *}$ \\
\hline & N. Changes $=2$ & 0.128 \\
\hline & N. Changes $=0$ & \\
\hline & Mode used, pre-pandemic $=$ Public and Private & $1.096^{*}$ \\
\hline & Mode used, pre-pandemic $=$ Public & $1.043 *$ \\
\hline & Mode used, pre-pandemic $=$ Private & \\
\hline & Previous use of electric vehicles $=$ Yes & -0.731 * \\
\hline & $\begin{array}{l}\text { Previous use of paratransit and micromobility } \\
\text { services }=\text { Yes }\end{array}$ & -0.004 \\
\hline
\end{tabular}

yellow: $\beta$ with "significant values", ${ }^{*}=\sigma<0.01,{ }^{* *}=\sigma<0.05 ;{ }^{\text {a }} c$ group Assumed-convenience behavior (no pass, or paratransit and micromobility) taken as a reference.

Table 5. Predictors for willingness to pay, correlations.

\begin{tabular}{llc}
\hline Willingness to Pay Options ${ }^{\mathbf{a}}$ & \multicolumn{1}{c}{ Variables } & $\boldsymbol{\beta}$ \\
\hline & Travel purpose = Work & -0.170 \\
& Travel purpose = Study & 0.632 \\
& Travel purpose = Other & $0 \mathrm{~b}$ \\
& Mode used, pre-pandemic = Public and Private & $1.310^{*}$ \\
& Mode used, pre-pandemic = Public & $1.608^{*}$ \\
& Mode used, pre-pandemic = Private & \\
& Living in Rome = Yes & -0.555 \\
\hline & Travel purpose = Work & 0.524 \\
& Travel purpose = Study $30 €$ & 0.848 \\
& Travel purpose = Other & \\
& Mode used, pre-pandemic = Public and Private & $1.199 *$ \\
& Mode used, pre-pandemic = Public & $1.316^{* *}$ \\
& Mode used, pre-pandemic = Private & \\
& Living in Rome = Yes & -0.503 \\
\hline
\end{tabular}


Table 5. Cont.

\begin{tabular}{|c|c|c|}
\hline Willingness to Pay Options ${ }^{a}$ & Variables & $\beta$ \\
\hline \multirow{7}{*}{ (c) More than $50 €$} & Travel purpose $=$ Work & 0.882 \\
\hline & Travel purpose $=$ Study & $1.429 * *$ \\
\hline & Travel purpose $=$ Other & \\
\hline & Mode used, pre-pandemic $=$ Public and Private & 1.383 * \\
\hline & Mode used, pre-pandemic $=$ Public & $1.725 *$ \\
\hline & Mode used , pre-pandemic $=$ Private & \\
\hline & Living in Rome $=$ Yes & $-1.510^{*}$ \\
\hline
\end{tabular}

Along with those, the "pay as you go" group (thus no subscription) was assumed as the reference one.

As in Table 4, students are central: "study" purposes, surprisingly, affect the willingness to pay more than 50 Euros, making students potential MaaS customers. Transit passengers (i.e., those associated with "Mode used, pre-pandemic = Public", in Table 5) can be associated with all the three cost options, which can be understood as a large share of respondents acknowledging the actual costs of MaaS operations.

The condition of living in Rome strongly affects group " $c$ " and this can be interpreted in two ways. One reason could be that living in Rome and having long experienced the transit supply make this demand disillusioned, thus the lack of willingness to pay more for a service assumed to be unsatisfactory, in line with the negative sentiment highlighted in [71]. Another reason could be the mild form of lockdown respondents were experiencing while participating in the survey, which could have prompted uncertainties in paying higher costs in a "new normal" horizon not that near.

\subsubsection{Gender-Specific Results}

Half of the 435 respondents were women, providing some interesting information on the perception of MaaS. In terms of profile and compared to their male peers, the female respondents are, on average, older, employed, but along with work $(35,8 \%)$ they also state "errands" among the most recurring travel purposes (Figure 4).

Both women and men state more or less the same rates of ownership of private cars and PTW (66.5\% of women, $62.7 \%$ of men), but just $3.7 \%$ in the female group own a micromobility mode, whereas this percentage reaches $10.1 \%$ among men. Likewise, men are more familiar with electric propulsion and sharing opportunities and have already used both types of vehicles more often than women. In turn, women state a greater willingness in knowing about these.

The pre-pandemic modal choice confirms women's higher familiarity with traditional modes, i.e., transit and private cars, although they use ride-hailing services more than their male peers (Figure 5).

When asked about the changes in their travel behaviors because of to the pandemic, women respondents state to have been highly affected, consistently with the observation of their higher share of transit ridership.

It is not surprising, then, that women's ideal MaaS bundle should include buses, parking, and ride-hailing, which places them in the Conventional behavior group. In line with this conservative approach, is their low willingness to pay for the bundle; for $42,3 \%$ of the female interviewees, this should cost less than the monthly transit pass (Figure 6).

\subsubsection{MaaS Bundle Choice According to Age, Income and Origin of Respondents}

Respondents' favored bundles if related to personal characteristics provides more insight for the development of the service. A specific cross-analysis interrelates the three bundles reported in Section 5.1.3, i.e., the Conventional behavior including transit and parking supply, the MaaS-friendly behavior including transit, paratransit, and micromobility services, 
and eventually the Assumed-convenience behavior including paratransit and micromobility services, with the respondents' age, income levels, and origin of the daily trips.

Results synthesized in Figure 7 confirms what was already observed about general preferences: Younger groups (age 15-35) are the MaaS-friendliest and most open to micromobility. This is not surprising, whereas the poor favor for the bundle Assumed-convenience behavior among the 36-45 group is rather unexpected, also because they are very similar to that of the senior interviewees (those older than 65 years). This qualifies the younger as target groups.

main travel purpose

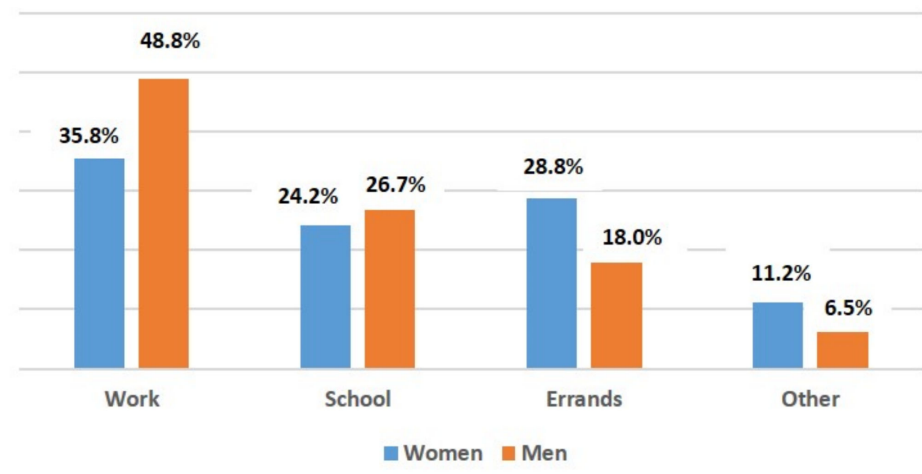

secondary travel purpose

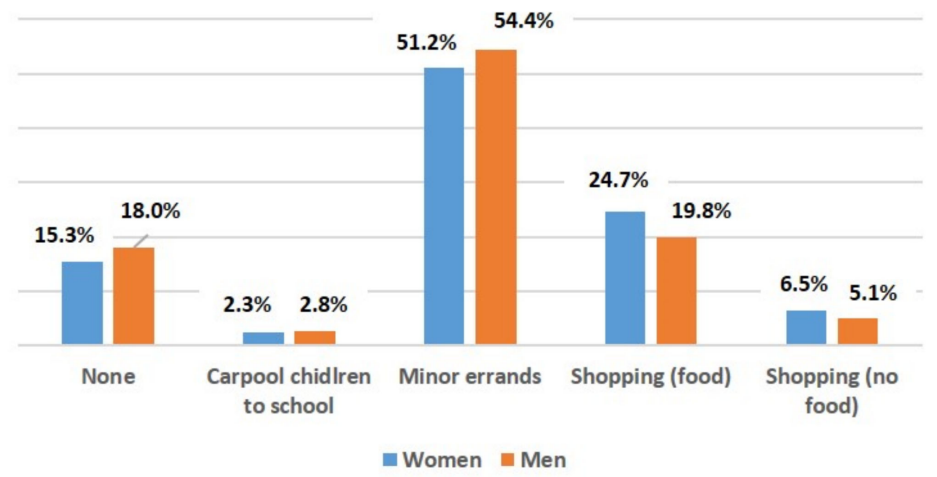

Figure 4. Travel purposes, according to gender.

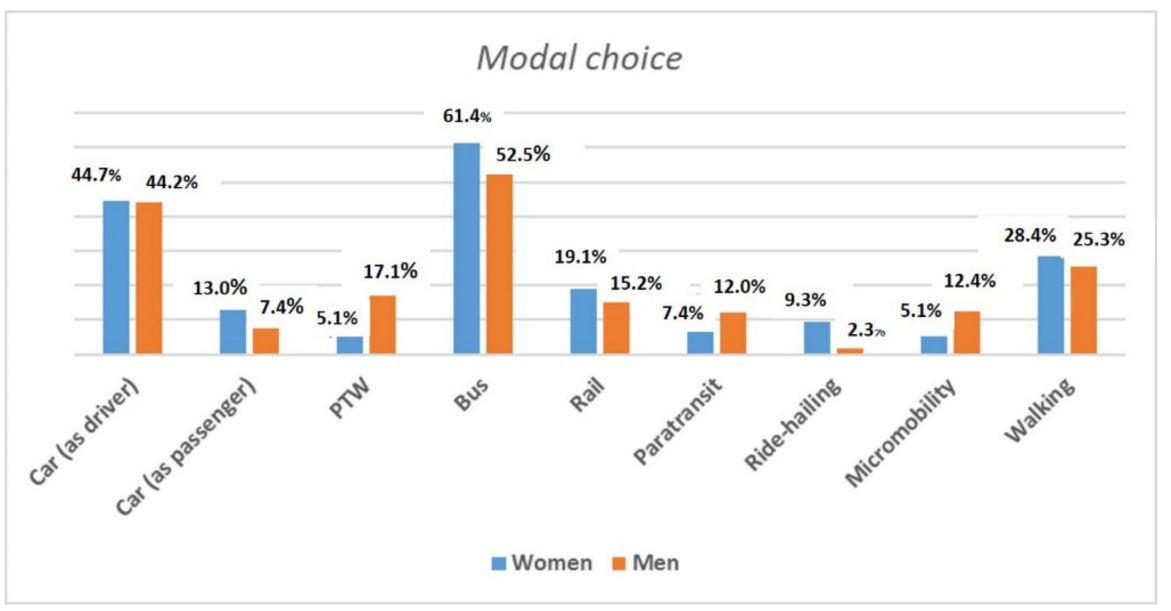

Figure 5. Modal choice, according to gender. 

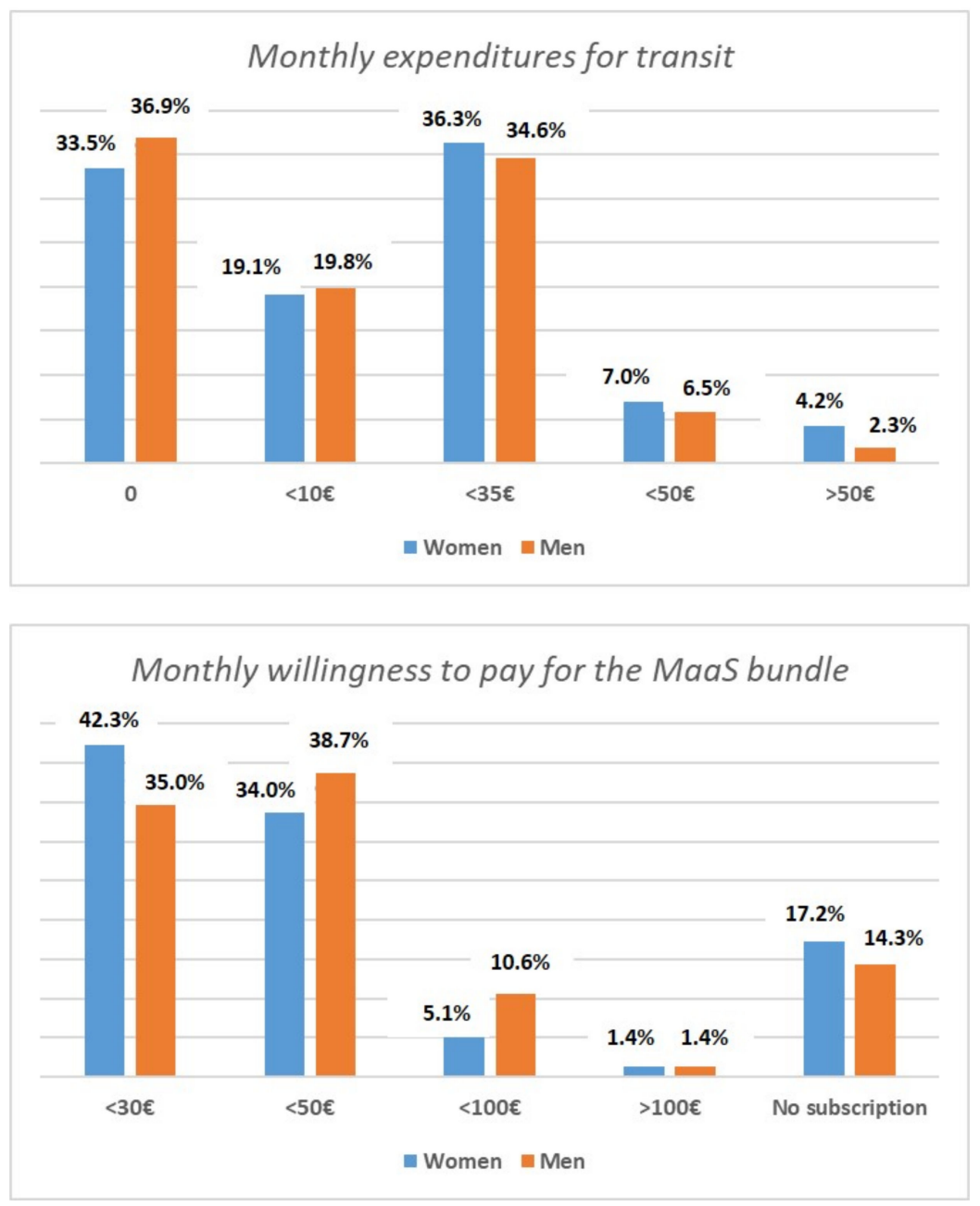

Figure 6. Current monthly expenditures for transit pass vs. willingness to pay for a given MaaS bundle, according to gender.

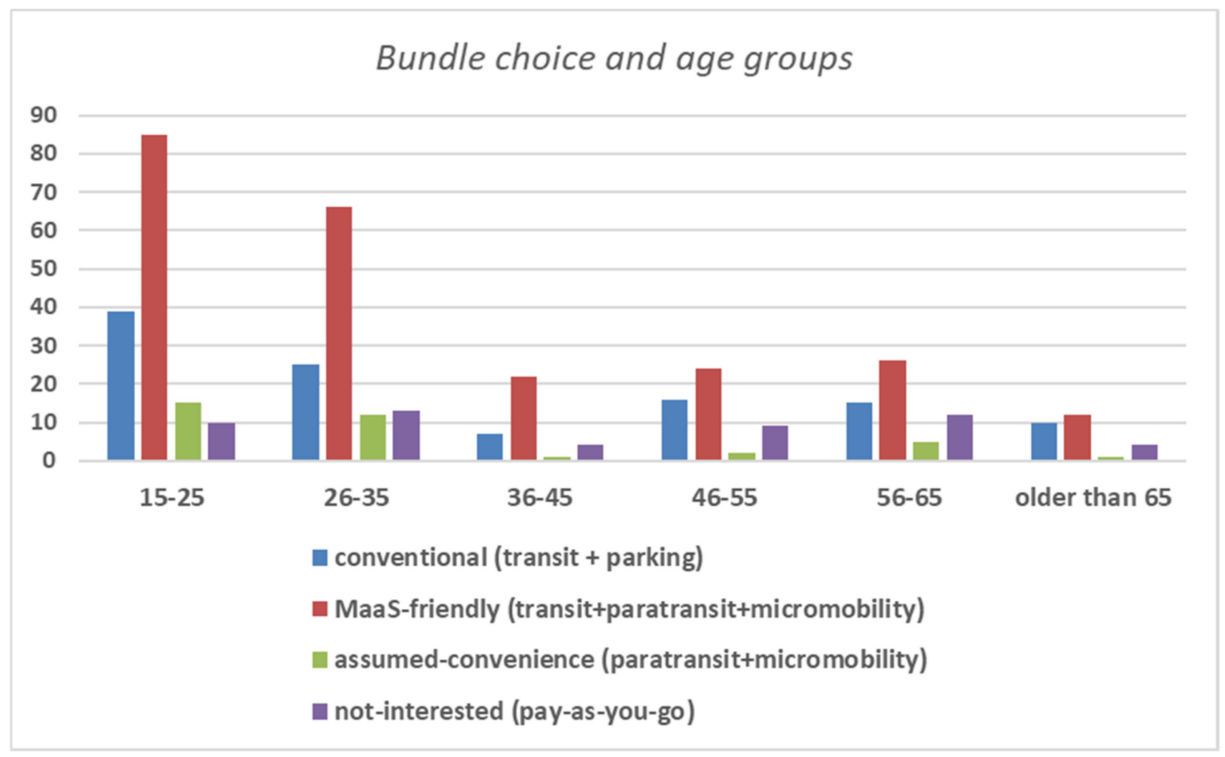

Figure 7. MaaS bundle choice, according to respondents' age.

The relationship between income levels and bundles (Figure 8) also confirms the willingness to pay of the less affluent (up to 25,000 Euros as yearly income, thus probably 
students and young hired employees); of note, from 25,000 Euros up those who are not interested in any subscription (pay-as-you-go option) markedly increase. However, the MaaS-friendly bundle is the most favored by any income group.

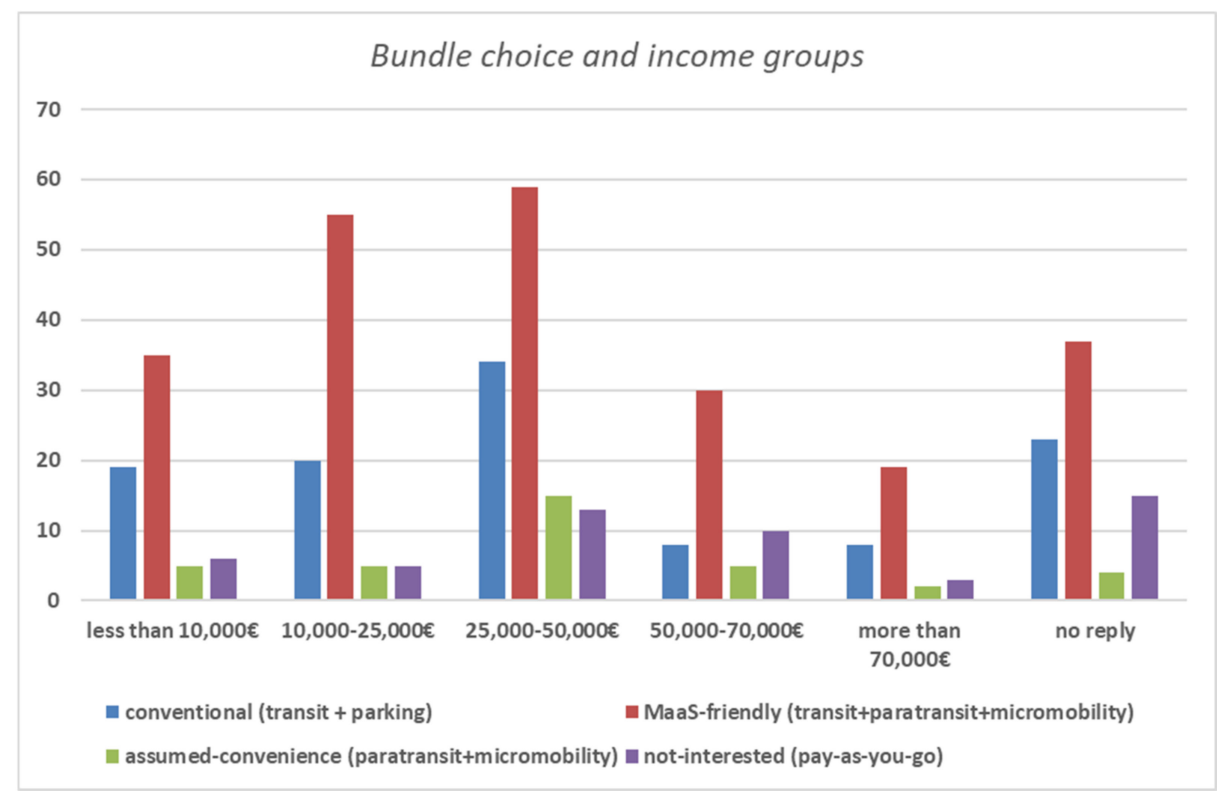

Figure 8. MaaS bundle choice, according to respondents' income levels.

The interrelation between bundles and origin of trips is based on the main assumption, i.e., zoning that divides the city in three areas: The city center (the black dot in Figure 3, left covering a small area of less than $20 \mathrm{sqkm}$ ); the consolidated city, with districts fully developed before World War II (i.e., all the areas abutting with the city center in Figure 3, left); and the outskirts, i.e., all the remaining areas). A fourth non-physical "area" is considered, corresponding to that of the daily commuters, living outside the city. Results are reported in Figure 9, and it is not surprising that nobody living in the city center is interested in the Conventional bundle; in this area, services are at walking distance, parking is free for those living there, and thus this bundle has no attraction. The same is valid for those living in the outskirts: Transit service performance is poorer here than in the more central areas and the pay-for-parking enforcement is rather modest. This generates inveterate drivers, tolerant to distance, for whom the Conventional is of no interest. The observation that in this area the bundle supplying the mix of paratransit and transit (the Assumed Convenience one) also seems to be not very attractive it is not surprising, either. Until the launch of the free-flow services, car sharing was not operated in this area and currently no micromobility is supplied, which means that poor interest is generated by the poor knowledge of these options. All in all, the results from Figure 9 seem to qualify residents of the consolidated areas and the commuters living outside the city as the main target groups.

\subsection{The Appropriate Business Model}

Considering the above results, students qualify as eligible customers for MaaS in Rome. This is confirmed by the BMC application, which also stresses a potential for the employees as a specific customer group. For both, the familiarity with paratransit and micromobility is an element of strength. For the students, this also represents a form of independence from private cars. For the employees, however, conventional transit supply still matters, but among them, a large group has "major mobility needs", for which conventional transit is not sufficient. This group states performing several trips to reach customers scattered across the city, accounting for an average of $50 \mathrm{~km}$ as a daily driven mileage. Driving is preferred to transit riding due to an assumed convenience, even though cruising for 
parking is not negligible and an admitted problem. Paratransit and micromobility in a potential bundle can certainly offer a solution to that, as the former on-street parking is free and parking is not an issue for the latter, due to the lack of consolidated regulations in Rome. Thus, free parking can be an element of attraction, also supported by flexibility (i.e., a combination of private, public and shared modes).

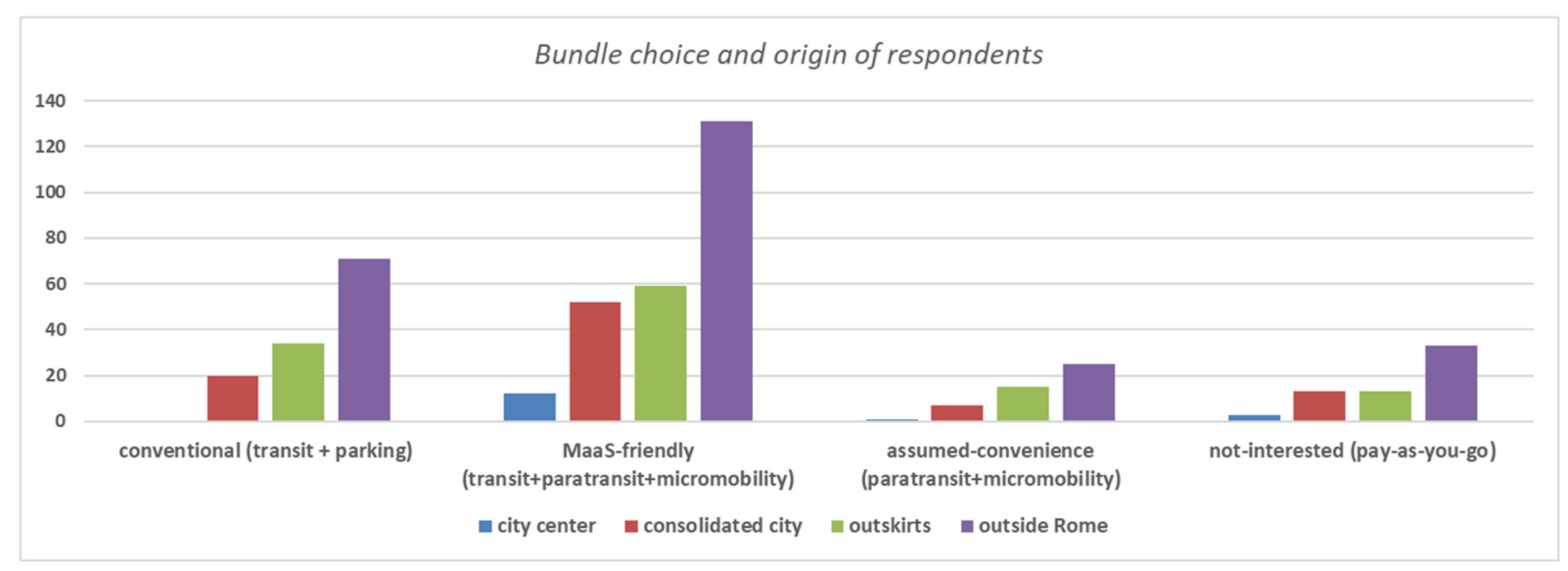

Figure 9. MaaS bundle choice, according to respondents' origin.

Within the BMC it was possible to profile two additional customer groups: "families" and "tourists". Families as a customer group has been already tested in Rome within the station-based car sharing supply, offering special rates. Although MaaS seems more related to the corporate culture, such an example and other case studies in Sweden seem to suggest that families could generate significant demand. In a city like Rome, a MaaS bundle for tourists could generate demand too, especially if well-advertised and integrated with other commercial opportunities (hotel accommodations, shuttle services to/from the airports, museums tickets, hop-on/hop-off coaches). However, as the majority of city landmarks and tourist attractions are within walking distance, a tourist bundle should be designed to enable tourists to also reach the sightseeing destinations in the surrounding municipalities (thus adding one sublevel to those mentioned in the literature in Section 2.1, i.e., the integration among the interested municipalities).

As to the cost and revenue schemes, the unavailability of data, due to the novelty of MaaS in Italy, forced us to develop qualitative assumptions based on the comparison with other local paratransit and mobility services rather than on those developed in Northern Europe, due to the general higher costs of living if compared with Italy. For example, a MaaS successful case study in Gothenburg, Sweden, with a subscription monthly rate of around 200 Euros [93], could hardly be taken as a reference, considering the SP in Figure 6. The same goes for other examples in the literature, synthesized in [94], with SP all above 100 Euros per month, just for unlimited transit ridership.

Among the different expenditure items, the bulkiest ones can be associated with staff and investments, within the service management and the customer care areas, and fleets' capital costs. Further expenditures associated with know-how, advertisement, and innovation also appear relevant. Nevertheless, in Italy, several national funds have been granted to support green mobility plans and programs recently, thus subsidies might be part of the preliminary budget. Concerning the revenue models, these hinge on two typical sale structures: Subscriptions or "pay as you go" schemes. In the former, incomes are generated as a surplus from the provider's buy-and-resell services from the transport operator(s) to the customers, with high revenues, but also a large portion of the investments costs falling directly on the provider. In the latter, the providers' incomes come from sale percentages. In Rome, any revenue schemes should rely on both: The "pay as you go" scheme is more suitable at the MaaS' inception, when customization is in the making and operations are focused on fine-tuning. Once the service is consolidated, subscriptions can be launched to 
increase revenues, capitalizing on the finalized customization process. To cap it all, the final $\mathrm{BMC}$ is reported in Figure 10, where the public transport operators currently operating in Rome are reported as potential players.

\begin{tabular}{|c|c|c|c|c|}
\hline Key Partners & Key activities & Value proposition & Customer Relationships & Customer Segments \\
\hline $\begin{array}{l}\text { - PT Operators: } \\
\text { ○ ATAC } \\
\circ \text { Cotral } \\
\circ \text { Trenitalia } \\
\circ \text { Roma TPL } \\
\text { - Infrastructure providers: } \\
\text { ○ City Authority } \\
\circ \text { Regional Authority } \\
\circ \text { Railway Operator } \\
\text { - Policy makers: } \\
\text { ○ City Authority } \\
\text { ○ Regional Authority } \\
\text { ○ National Authority } \\
\text { - Sharing mobility } \\
\text { companies } \\
\text { - Data and content } \\
\text { providers } \\
\text { - External Payment } \\
\text { gateways } \\
\text { (PayPal, Sisal, CartaSI, } \\
\text { Banks) } \\
\text { - Tourist Operators }\end{array}$ & $\begin{array}{l}\text { - Platform development } \\
\text { \& maintenance } \\
\text { - Service provision: } \\
\text { ○ journey planner } \\
\text { ○ booking } \\
\text { ○ ticketing } \\
\text { ○ payment } \\
\text { ○ customer support } \\
\text { - Marketing, promotion } \\
\text { \& commercialization }\end{array}$ & $\begin{array}{l}\text { - Seamless, integrated, } \\
\text { multimodal travel } \\
\text { experience } \\
\text { - Interoperability of } \\
\text { services } \\
\text { - Journey planning, } \\
\text { booking, ticketing and } \\
\text { payment altogether in } \\
\text { one single environment } \\
\text { - Unique selling point for } \\
\text { a wide range of services } \\
\text { - Convenience, } \\
\text { accessibility, flexibility } \\
\text { and sustainability goals } \\
\text { - Personalization of the } \\
\text { service on the users' } \\
\text { needs } \\
\text { - Pollution and car } \\
\text { reliance decrease over } \\
\text { the long period }\end{array}$ & $\begin{aligned} & \text { Channels } \\
& \text { - Web } \\
& \text { - App } \\
& \text { - (Social) medias } \\
& \text { - Advertising campaigns } \\
& \text { - Community groups } \\
& \text { - Third party retailers }\end{aligned}$ & $\begin{array}{l}\text { - Individuals/private } \\
\text { users } \\
\circ \text { Young \& students } \\
\circ \text { Workers } \\
\circ \text { Tourists } \\
\text { - Families } \\
\text { - Companies } \\
\text { - Authorities (data } \\
\text { - Trans) }\end{array}$ \\
\hline \multicolumn{2}{|c|}{ Cost Structures } & \multicolumn{3}{|c|}{ Revenue Streams } \\
\hline \multicolumn{2}{|c|}{$\begin{array}{l}\text { - Investment costs: } \\
\text { o Platform/app design \& development } \\
\text { o Brand creation } \\
\text { - Operational Costs: } \\
\text { o amortization of investments } \\
\text { o software and information system maintenance } \\
\text { o legal related costs } \\
\text { o marketing } \\
\text { o service provision \& customer service }\end{array}$} & \multicolumn{2}{|c|}{$\begin{array}{l}\text { - Commissions on ticket sales (PAYG } \\
\text { - Revenues from packages sales } \\
\text { - } \text { Advertising on app and website } \\
\text { Deselling and consulting servic }\end{array}$} & \\
\hline
\end{tabular}

Figure 10. The Business Model Canvas for the Rome case study.

\section{Discussing Maturity for MaaS in Rome}

The results presented in the previous section clearly indicate lights and shadows within the five dimensions of maturity required to implement MaaS [27], which can be divided into two major areas: Technical viability and social acceptance. Issues of data sharing and cooperation among the operators, ICT infrastructure quality, and transport services and infrastructure can be associated with the former, whereas social acceptance relies on the set of regulatory and policy actions, which create awareness and recognition among the citizens and, consequently, build their familiarity and willingness to use the service.

When discussing the level of maturity for a MaaS application in Rome, the technical viability is not in dispute. Multimodality and integration of services and fares are already in place, albeit not as within a typical MaaS ecosystem. Moreover, operators, given the conservative policy thus far enforced, would certainly benefit from new governance based on cooperation and heterarchy. The general remark that in some cases the local level of integration might be not enough [38] can be true for Rome too. At the same time, there is no evidence of unfeasibility in upgrading it; the same goes for the technical solutions of problems related to data sharing.

Yet, observing the SP on the potential bundles and the willingness to pay among the respondents for them, there is clearly little recognition for MaaS, which shifts the focus on its social acceptance. Conventional behaviors are strong (as shown by the relevance of transit and parking in the bundles), and the modest willingness to pay is a consequence: As long as private cars prevail, transit remains just the ersatz mode to destinations where cruising for parking is the problem. The willingness of many respondents to pay less than 30 Euros can be explained by the general underestimation of costs related to transport, due to several factors (cheap parking fees, with a 70-Euros monthly plan enabling unlimited onstreet parking; regular ticket offenses; unsatisfying transit supply). Therefore, respondents 
have little interest in innovative forms like paratransit and micromobility, unless driven by necessity or because attracted by the novelty.

The respondents' age could also be factored in: Young people seem more attracted by bundles combining public and sharing services, and among them, the youngest prefer micromobility over paratransit. The youngsters' behavior is in line with the general rhetoric around MaaS [95] and the optimism observed in much of the literature, which banks on the favor with which innovation is generally saluted (not only in transport policies and mobility governance).

At the same time, little satisfaction with the current transit supply explains the conventional behaviors among the elder interviewees, i.e., their reason to keep on driving rather than riding, as suggested by the relevance of parking in the bundles. They seem to perceive $\mathrm{MaaS}$ as an addendum to the integrated services already supplied. This can be interpreted in different ways: Poor confidence in the possibility to enhance the quality of conventional transit, given the long-lamented problems highlighted in Section 3.1; little knowledge of MaaS' potential, also worsened by the pandemic's uncertainties and consequent reduced mobility needs at the time the questionnaire was submitted; and the myth of private cars' higher convenience over transit, still difficult to debunk.

\subsection{Making MaaS Accepted as a Goal to Rebalance the Local Modal Share}

The lesson to be learned is that in typical conservative contexts like Rome, to introduce innovations, social acceptance is the major issue to address, within the general goal to rebalance the modal share in favor of collective modes. Building social acceptance implies the development of shared policies to create awareness, familiarity, and satisfaction, as a result of the interrelation among actors, problems, and actions, where solutions to be achieved rely on a relative "optimum". In the Rome case (Table 6), an interrelation matrix is proposed, where each row represents a typical problem associated with the local conservativeness, and the columns show action areas to have MaaS successfully implemented. These, all aimed at increasing the responsiveness to MaaS and rebalance the modal share, are:

- Transit as a leading mode in the bundle: In the long run, bundles based on the "Assumedconvenience behavior" (i.e., without any form of public transport included), or emphasizing the paratransit or micromobility components, simply replicate private cars' "solo" driving behaviors, although at a sharing scale. In a conservative context like Rome, the public would perceive MaaS as the "business class" in the local modal share and public transport as the "economy" one. This represents one more factor in the issue of equity within Maas [96] and certainly would hardly diminish the car-reliance. Therefore, transit must be the core mode in every bundle.

- Parking only for virtuous behaviors: As long as parking is cheap, this option in a bundle will only foster the use of private cars and the perception of its low cost in a mix of mobility supply like paratransit and micromobility, perceived as more expensive. A possibility is to include parking as an additional option in a given bundle under specific conditions (limited amount of hours, selected destinations), with its cost to be added to that of the bundle itself. Customers will perceive the actual value of parking and will opt for it only if need be.

- Eco-friendly customization: Respondents' interest in bonuses indicates the actual possibility to convert regular passengers in service customers, in line with the "consumergroup" sentiment highlighted in [55]. Bonuses can be used to increase the environmental consciousness, which seems not very high among the respondents. Such additional benefits could be associated with specific options, for example when customers decide "to go electric" or have a major share of public transport in the bundle. This could steer the public perception to consider that bonuses can be granted according to the use of cleaner modes, improving the general environmental awareness.

- Education and information: Both can be aimed at conveying among the customers that MaaS can both rebalance the modal share in favor of collective transport and help to 
qualify public transport; increasing the awareness that transport is a commodity like any other goods, subjected to market laws but at the same time universally accessible and affordable. This should develop a greater willingness to pay.

- Public Private Partnership: This seems the only way to ensure, at the same time, appropriate control, community involvement, efficiency, and profitability of the MaaSgenerated ecosystem in a city like Rome. It could balance the management between business and community interests, but above all, steer the transition from monopoly to heterarchy. In this, PPP could be a driver in increasing the quality of public transport, since a plurality of services and operators are often synonym of competition in attracting customers. A high-quality bus service briefly introduced in Rome, during the 2000 Holy Year, turned out to be very appreciated, as was the private taxibus service operated for a short period, some years after [71]. Both cases evidence that PPP could be feasible and appropriate.

- Regularity and full-scale: Discontinued, pilot-sized implementation conveys the idea that MaaS is a "niche" and temporary service. Success can be claimed only when a service consolidates and generates profit, which means that solid business plans are needed, subsidies should be limited at the inception phases, and regulatory support should be constant and comprehensive.

Specific Measures for Implementing MaaS in Rome

Measures to move towards actual implementation should be framed within four specific domains: Regulations, organization, information, and operations. Concerning regulations, as stated, MaaS is included in the local SUMP and in the more recent Smart Rome plan [97] where an innovative e-ticketing system is specifically planned to accommodate MaaS operations. However, without an actual implementation (including timeframes, actors, responsibilities, resources, operations, and performance targets), MaaS can hardly find real application in Rome. The organizational domain is the consequent step, with the translation of the business plan directions into operational plans coherent with the implementation plan. A sensitive task, in this step, can be the appointment of the service broker or integrator, with this role being novel in the city. The last two domains, education and operation, should go hand in hand. Citizens should be informed on the opportunities supplied by MaaS and be made aware of its actual costs so as to overcome the modest willingness to pay. Media can be a very efficient resource in this, and also in conveying the message that the service is meant for everybody. Increased awareness and acceptance could be reached only if the "mediatization" process can be fostered by actual implementation, which in the case of Rome could take place by launching the service full scale, to avoid the impression that the service is limited to some areas or a "niche" for a few customer types. A smooth process would lead to the success of operations and the full public acceptance, which might also trigger an innovative People Public Private Partnership, with citizens actively involved in the bundle creation and the development of this new business model. 
Table 6. The interrelation matrix.

\begin{tabular}{|c|c|c|c|c|c|c|c|}
\hline \multicolumn{2}{|c|}{ Conservative Context } & \multicolumn{6}{|c|}{ Actions to Increase Receptiveness to MaaS and Rebalance the Modal Share } \\
\hline Features & Problems & $\begin{array}{l}\text { Ecofriendly } \\
\text { Customization }\end{array}$ & $\begin{array}{l}\text { Transit as Leading } \\
\text { Mode in the Bundle }\end{array}$ & $\begin{array}{l}\text { Parking Only for the } \\
\text { Virtuous Behaviors }\end{array}$ & $\begin{array}{l}\text { Education and } \\
\text { Information }\end{array}$ & PPP & $\begin{array}{l}\text { Regularity and } \\
\text { Full-Scale: }\end{array}$ \\
\hline Monopolistic approach & $\begin{array}{l}\text { One operator as major } \\
\text { player in the transit } \\
\text { supply }\end{array}$ & & & & & $\begin{array}{l}\text { Generate heterarchy } \\
\text { and plurality of services }\end{array}$ & \\
\hline $\begin{array}{l}\text { Unbalanced modal } \\
\text { share }\end{array}$ & $\begin{array}{l}\text { Private cars as } \\
\text { prevailing mode }\end{array}$ & $\begin{array}{l}\text { Attract passengers to } \\
\text { transit }\end{array}$ & $\begin{array}{l}\text { Attract passengers to } \\
\text { transit }\end{array}$ & $\begin{array}{l}\text { Attract passengers to } \\
\text { transit }\end{array}$ & $\begin{array}{l}\text { Attract passengers to } \\
\text { transit }\end{array}$ & & \\
\hline $\begin{array}{l}\text { Not consolidated } \\
\text { paratransit supply }\end{array}$ & $\begin{array}{l}\text { Different options, not } \\
\text { always lasting }\end{array}$ & & & & Consolidate supply & & Consolidate supply \\
\hline $\begin{array}{l}\text { Not consolidated } \\
\text { micromobility supply }\end{array}$ & $\begin{array}{l}\text { Booming of rental } \\
\text { options, uncertainties in } \\
\text { the development }\end{array}$ & & & & Consolidate supply & & Consolidate supply \\
\hline Cheap parking & Low parking charges & & & Introduce restrictions & & & \\
\hline Poor transit quality & $\begin{array}{c}\text { Reiterated citizens' poor } \\
\text { satisfaction }\end{array}$ & & & & & $\begin{array}{l}\text { Increase quality by } \\
\text { competing services }\end{array}$ & \\
\hline $\begin{array}{l}\text { Modest willingness to } \\
\text { pay for transit }\end{array}$ & Ticket offenses & & & $\begin{array}{c}\text { Awareness of the } \\
\text { magnitude of transport } \\
\text { costs }\end{array}$ & & & \\
\hline
\end{tabular}




\section{Conclusions}

The Rome case study provides an analysis of drivers and barriers to implement MaaS in contexts where maturity might be in dispute due to long-enforced conservative mobility policies. This goes beyond the mere technological transfer of data and operational know-how and integration management, often highlighted in the literature as elements of maturity, since in Rome, both are feasible and also planned by the local Sustainable Urban Mobility Plan.

The maturity issue is addressed in terms of social acceptance and responsiveness to MaaS, and is valid for any urban area where, as in Rome, cars have the major share, parking is low-priced, public transport is poorly attractive, paratransit and micromobility still operating as niche services, and governance is still based on monopolistic basis. The survey responses reflect all these problems, and the contrast between the readiness to adopt MaaS and the modest willingness to pay for it is conspicuous. This evidences that MaaS can hardly be introduced without citizens becoming aware that transit services are commodities like any other goods. In the case of Rome, such unawareness is even more evident when taking into consideration one more contrast: As shown by the favor stated for the bonuses, the survey respondents are well into the general "consumer" logic, except for what concerns the transport services.

For the Rome case, the conclusion could be that there is a fertile ground for MaaS, but here, and in other conservatively oriented cities, maturity means to operate policies where PPP, the centrality of public transport in the bundles, customization dedicated to raise environmental consciousness along with participation of the citizens via information and education are the actual avenues to explore, if MaaS is implemented to rebalance the local modal share in favor of collective modes.

The analysis of this case study is currently progressing with one more field of applications: A study on the opportunities of MaaS as a statutory transportation option, to meet the requirements of the senior population.

Author Contributions: Conceptualization and methodology, M.V.C.; formal analysis and validation, M.V.C.; investigation, M.V.C. and G.C.; data curation, G.C.; writing-review and editing, M.V.C. All authors have read and agreed to the published version of the manuscript.

Funding: This research received no external funding.

Institutional Review Board Statement: Not applicable.

Informed Consent Statement: Not applicable.

Data Availability Statement: Data available on request due to privacy.

Acknowledgments: The Authors wish to thank Daniela Vasari for her valuable support during the business model study.

Conflicts of Interest: The authors declare no conflict of interest.

\section{References}

1. Heikkilä, S. Reorganization of the Mobility Service provision-Public governance as a contributor. In Proceedings of the 21st World Congress on Intelligent Transport Systems, ITSWC 2014: Reinventing Transportation in Our Connected World, Detroit, MI, USA, 7-11 September 2014; Intelligent Transportation Society of America: Washington, DC, USA, 2014.

2. Reck, D.; Hensher, D.A.; Ho, C.Q. MaaS bundle design. Transp. Res. Part A Policy Pract. 2020, 141, 485-501. [CrossRef]

3. Rantasila, K. The impact of Mobility as a Service concept to land use in Finnish context. In Proceedings of the International Conference on Sustainable Mobility Applications, Renewables and Technology (SMART), Kuwait City, Kuwait, 23-25 November 2015.

4. Expósito-Izquierdo, C.; Expósito-Márquez, A.; Brito-Santana, J. Mobility as a Service. In Smart Cities: Foundations, Principles, and Applications; Song, H., Srinivasan, R., Sookoor, T., Jeschke, S.T., Eds.; Wiley: London, UK, 2017; pp. 409-435.

5. Weekes, S. MaaS Alliance Expands Footprint into Asia. Smart Cities World. 12 November 2019. Available online: https: //www.smartcitiesworld.net/news/news/maas-alliance-expands-footprint-into-asia-4774 (accessed on 2 May 2020).

6. Eckhardt, J.; Nykänen, L.; Aapaoja, A.; Niemi, P. MaaS in rural areas-case Finland. Res. Transp. Bus. Manag. 2018, $27,75-83$. [CrossRef] 
7. Barreto, L.A.; Amaral, A.; Baltazar, S. Mobility as a Service (MaaS) in rural regions: An overview. In Proceedings of the 2018 International Conference on Intelligent Systems (IS), Funchal, Portugal, 25-27 September 2018; pp. 856-860.

8. Utriainen, R.; Pöllänen, M. Review on mobility as a service in scientific publications. Res. Transp. Bus. Manag. 2018, 27, 15-23. [CrossRef]

9. Kamargianni, M.; Li, W.; Matyas, M.; Schäfer, A. A Critical Review of New Mobility Services for Urban Transport. Transp. Res. Proc. 2016, 14, 3294-3303. [CrossRef]

10. Arias-Molinares, D.; García-Palomares, J.C. The Ws of MaaS: Understanding mobility as a service from a literature review. IATSS Res. 2020, 44, 253-263. [CrossRef]

11. Karlsson, I.C.M.; Mukhtar-Landgren, D.; Smith, G.; Koglin, T.; Kronsell, A.; Lund, E.; Sarasini, S.; Sochor, J. Development and implementation of Mobility-as-a-Service-A qualitative study of barriers and enabling factors. Transp. Res. Part A Policy Pract. 2020, 131, 283-295. [CrossRef]

12. Feneri, A.M.; Rasouli, S.; Timmermans, H.J.P. Modeling the effect of Mobility-as-a-Service on mode choice decisions. Transp. Lett. 2020, 1-9. Available online: https:/ / www.tandfonline.com/doi/full/10.1080/19427867.2020.1730025 (accessed on 25 January 2021). [CrossRef]

13. Alyavina, E.; Nikitas, A.; Tchouamou Njoya, E. Mobility as a service and sustainable travel behaviour: A thematic analysis study. Transp. Res. Part F Traffic Psychol. Behav. 2020, 73, 362-381. [CrossRef]

14. Durand, A.; Harms, L.; Hoogendoorn-Lanser, S.; Zijlstra, T. Mobility-as-a-Service and Changes in Travel Preferences and Travel Behaviour: A Literature Review; KiM Netherlands Institute for Transport Policy Analysis: The Hague, The Netherlands, 2018; pp. 15-26.

15. Reyes García, J.R.; Lenz, G.; Haveman, S.P.; Bonnema, G.M. State of the Art of Mobility as a Service (MaaS) Ecosystems and Architectures-An Overview of, and a Definition, Ecosystem and System Architecture for Electric Mobility as a Service (eMaaS). World Electr. Veh. J. 2020, 11, 7. [CrossRef]

16. Reck, D.J.; Axhausen, K.W. How much of which mode? Using revealed preference data to design mobility as a service plans. Transp. Res. Rec. 2020, 2674, 494-503. [CrossRef]

17. Sarasini, S.; Sochor, J.; Arby, H. What characterises a sustainable MaaS business model? In Proceedings of the 1st International Conference on Mobility as a Service (ICOMaaS), Tampere, Finland, 28-29 November 2017.

18. Aapaoja, A.; Eckhardt, J.; Nykänen, L. Business models for MaaS. In Proceedings of the 1st International Conference on Mobility as a Service (ICOMaaS), Tampere, Finland, 28-29 November 2017.

19. Wong, Y.Z.; Hensher, D.A. Delivering mobility as a service (MaaS) through a broker/aggregator business model. Transportation 2020, 1-27. Available online: https:/ /link.springer.com/article/10.1007/s11116-020-10113-z\#citeas (accessed on 25 January 2021). [CrossRef]

20. Jittapirom, P.; Caiati, V.; Feneri, A.M.; Ebrahimigharehbaghi, S.; Alonso González, M.J.; Naraya, J. Mobility as a Service: A Critical Review of Definitions, Assessments of Schemes, and Key Challenges. Urban Plan. 2017, 2, 13-25. [CrossRef]

21. Audouin, M.; Finger, M. The development of Mobility-as-a-Service in the Helsinki metropolitan area: A multi-level governance analysis. Res. Transp. Bus. Manag. 2018, 27, 24-35. [CrossRef]

22. Stone, T. Finnish Government Supports Unique MaaS Pilot Project in Tampere. Traffic Technology Today. 11 October 2017. Available online: https:/ / www.traffictechnologytoday.com/news/smart-cities/finnish-government-supports-unique-maaspilot-project-in-tampere.html (accessed on 20 November 2020).

23. Jittrapirom, P.; Marchau, V.; van der Heijden, R.; Meurs, H. Dynamic adaptive policymaking for implementing Mobility-as-a Service (MaaS). Res. Transp. Bus. Manag. 2018, 27, 46-55. [CrossRef]

24. Smith, G.; Sochor, J.; Karlsson, I.M. Public-private innovation: Barriers in the case of mobility as a service in West Sweden. Public Manag. Rev. 2019, 21, 116-137. [CrossRef]

25. Ho, C.Q.; Hensher, D.A.; Reck, D.J.; Lorimer, S.; Lu, I. MaaS bundle design and implementation: Lessons from the Sydney MaaS trial. Transp. Res. Part A Policy Pract. 2021, 149, 339-376. [CrossRef]

26. Li, Y. The Role of Public Authorities in the Development of Mobility-as-a-Service. In The Governance of Smart Transportation Systems; Finger, M., Audouin, M., Eds.; Springer: Cham, Switzerland, 2019; pp. 229-245.

27. Kamargianni, M.; Goulding, R. The Mobility as a Service Maturity Index: Preparing the Cities for the Mobility as a Service Era. In Proceedings of the 7th Transport Research Arena TRA 2018, Vienna, Austria, 16-19 April 2018.

28. Li, Y.; Voege, T. Mobility as a Service (MaaS): Challenges of Implementation and Policy Required. J. Transp. Technol. 2017, 7, 95-106. [CrossRef]

29. Butler, L.; Yigitcanlar, T.; Paz, A. Barriers and risks of Mobility-as-a-Service (MaaS) adoption in cities: A systematic review of the literature. Cities 2021, 109, 103036. [CrossRef]

30. MaaS Alliance. White Paper. 2017. Available online: https://maas-alliance.eu/wp-content/uploads/sites/7/2017/09/MaaSWhitePaper_final_040917-2.pdf (accessed on 20 November 2020).

31. Kamargianni, M.; Matyas, M. The Business Ecosystem of Mobility as a Service. In Proceedings of the 96th Transportation Research Board Annual Meeting, Washington, DC, USA, 8-12 January 2017.

32. Hietanen, S. "Mobility as a Service"-The new transport model? Eurotransport 2014, 12, 2-4.

33. Smith, G.; Mobility, G. As a Service and Public Transport. In The Routledge Handbook of Public Transport; Mulley, C., Nelson, J., Ison, S., Eds.; Routledge: London, UK, 2021; pp. 33-45. 
34. Dotter, F. Mobility-as-a-Service: A new transport model. CIVITAS Insight 2016, 18, 1-12.

35. Giesecke, R.; Surakka, T.; Hakonen, M. Conceptualising Mobility as a Service. In Proceedings of the 2016 Eleventh International Conference on Ecological Vehicles and Renewable Energies (EVER), Monte Carlo, Monaco, 6-8 April 2016.

36. Lyons, G.; Hammond, P.; Mackay, K. Reprint of: The importance of user perspective in the evolution of MaaS. Transp. Res. Part A Policy Pract. 2020, 131, 20-34. [CrossRef]

37. Tomaino, G.; Teow, J.; Carmon, Z.; Lee, L.; Ben-Akiva, M.; Chen, C.; Leong, W.Y.; Li, S.; Yang, N.; Zhao, J. Mobility as a service (MaaS): The importance of transportation psychology. Mark. Lett. 2020, 31, 419-428. [CrossRef]

38. Sochor, J.; Arby, H.; Karlsson, I.C.M.; Sarasini, S. A topological approach to Mobility as a Service: A proposed tool for understanding requirements and effects, and for aiding the integration of societal goals. Res. Transp. Bus. Manag. 2018, 27, 3-14. [CrossRef]

39. Poliak, M.; Mrnikova, M.; Jaskiewicz, M.; Jurecki, R.; Kaciakova, B. Public transport integration. Commun. Sci. Lett. Univ. Zilina 2017, 19, 127-132.

40. Luk, J.; Olszewski, P. Integrated public transport in Singapore and Hong Kong. Road Transp. Res. 2003, $12,41-51$.

41. Karinsalo, A.; Halunen, K. Smart Contracts for a Mobility-as-a-Service Ecosystem. In Proceedings of the 2018 IEEE International Conference on Software Quality, Reliability and Security Companion (QRS-C), Lisbon, Portugal, 16-20 July 2018.

42. Smith, G.; Sochor, J.; Karlsson, I.C.M. Intermediary MaaS Integrators: A case study on hopes and fears. Transp. Res. Part A Policy Pract. 2020, 131, 163-177. [CrossRef]

43. Hensher, D.; Ho, C.Q.; Reck, D.J. Mobility as a service and private car use: Evidence from the Sydney MaaS trial. Transp. Res. Part A Policy Pract. 2021, 145, 17-33. [CrossRef]

44. Chang, J.; Chen, H.Y.; Chen, H.C. Mobility as a service policy planning, deployments and trials in Taiwan. IATSS Res. 2019, 43, 210-218. [CrossRef]

45. Jang, S.; Caiati, V.; Rasouli, S.; Timmermans, H.; Choi, K. Does MaaS contribute to sustainable transportation? A mode choice perspective. Int. J. Sustain. Transp. 2021, 15, 351-363. [CrossRef]

46. Bousse, Y.; Corazza, M.V.; Arriaga, D.S.; Sessing, G. Electrification of public transport in Europe: Vision and practice from the ELIPTIC project. In Proceedings of the 2018 IEEE International Conference on Environment and Electrical Engineering and 2018 IEEE Industrial and Commercial Power Systems Europe (EEEIC/I\&CPS Europe), Palermo, Italy, 12-15 June 2018; pp. 1-6.

47. Smith, G.; Sochor, J.; Sarasini, S. Mobility as a service: Comparing developments in Sweden and Finland. Res. Transp. Bus. Manag. 2018, 27, 36-45. [CrossRef]

48. Cuthbert, A.R. Understanding Cities. Method in Urban Design; Routledge: London, UK, 2011; pp. 62-70.

49. Lund, E. Feasibility Study MaaS—A Business Case for EC2B; Trivector: Stockholm, Sweden, 2016; pp. 9-12.

50. Zhao, X.; Vaddadi, B.; Sjöman, M.; Hesselgren, M.; Pernestål, A. Key barriers in MaaS development and implementation: Lessons learned from testing Corporate MaaS (CMaaS). Transp. Res. Interdiscip. Perspect. 2020, 8, 100227.

51. König, D.; Eckhardt, J.; Aapaoja, A.; Karlsson, I.C.M.; Sochor, J. Deliverable 3: Business and Operator Models for MaaS. MAASiFiE Project Report. 2016. Available online: https://publications.lib.chalmers.se/records/fulltext/239795/local_239795.pdf (accessed on 18 January 2021).

52. Polydoropoulou, A.; Pagoni, I.; Tsirimpa, A.; Roumboutsos, A.; Kamargianni, M.; Tsouros, I. Prototype business models for Mobility-as-a-Service. Transp. Res. Part A Policy Pract. 2020, 131, 149-162. [CrossRef]

53. Samani, R.; Honan, B.; Reavis, J. The Cloud Threat Landscape. In CSA Guide to Cloud Computing; Samani, R., Honan, B., Reavis, J., Eds.; Syngress: Rockland, MA, USA, 2015; pp. 35-61.

54. Datson, J. Exploring the Opportunity for Mobility as a Service in the UK; Transport Systems Catapult: Milton Keynes, UK, 2016; pp. 18-26.

55. Schikofsky, J.; Dannewald, T.; Kowald, M. Exploring motivational mechanisms behind the intention to adopt mobility as a service (MaaS): Insights from Germany. Transp. Res. Part A Policy Pract. 2020, 131, 296-312. [CrossRef]

56. Karlsson, I.C.M.; Sochor, J.; Strömberg, H. Developing the 'Service' in Mobility as a Service: Experiences from a Field Trial of an Innovative Travel Brokerage. Transp. Res. Procedia 2016, 14, 3265-3327. [CrossRef]

57. Gandia, R.; Antonialli, F.; Nicolaï, I.; Sugano, J.; Oliveira, J.; Oliveira, I. Casual Carpooling: A Strategy to Support Implementation of Mobility-as-a-Service in a Developing Country. Sustainability 2021, 13, 2774. [CrossRef]

58. Anon. Auto Mia Quanto Mi Costi. La Repubblica. 7 March 2018. Available online: www.repubblica.it/economia/rapporti/ osserva-italia/mercati/2018/03/07/news /auto_mia_quanto_mi_costi_oltre_1_500_euro_all_anno-190583924/ (accessed on 10 March 2019).

59. Founta, A.; Papadopoulou, O.; Kalakou, S.; Georgiadis, G. Building Capacity of Small-Medium Cities' Local Authorities to Implement MaaS and Other Innovative Transport Schemes. Advances in Mobility-As-a-Service Systems. Adv. Intell. Syst. Comput. 2020, 1278, 359-367.

60. Rupprecht Consult (Ed.) Guidelines for Developing and Implementing a Sustainable Urban Mobility Plan; Rupprecht Consult Forschung \& Beratung GmbH: Cologne, Germany, 2019; Available online: https:/ /www.eltis.org/sites/default/files/sump-guidelines-2019 _mediumres.pdf (accessed on 25 January 2021).

61. ERTICO-ITS Europe (Ed.) Mobility as a Service (MaaS) and Sustainable Urban Mobility Planning; ERTICO-ITS Europe: Brussels, Belgium, 2019; Available online: https://www.eltis.org/sites/default/files/mobility_as_a_service_maas_and_sustainable_ urban_mobility_planning.pdf (accessed on 25 January 2021). 
62. Le Squeren, Z. Plural Governance for the Management of Local Public Services: An Empirical Investigation on the French Car Park Industry. Management 2020, 4, 28-43.

63. Comune di Roma. Piano Urbano della Mobilità Sostenibile. 2018. Available online: https://www.pumsroma.it/download/ Volume1-allegato-D251-18_2.pdf (accessed on 5 June 2020).

64. Comune di Roma, Roma Mobilità. Rapporto della Mobilità. 2020. Available online: https://romamobilita.it/sites/default/files/ RSM_RapportoMobilit\%C3\%A0_2020_Web_.pdf (accessed on 5 June 2020).

65. Anon. Un altro autobus in fiamme a Roma: Distrutta la vettura dell'Atac. Il Tempo. 27 January 2021. Available online: https: / / www.iltempo.it/roma-capitale/2021/01/27/news/autobus-fiamme-roma-casilina-incendio-atac-vigili-del-fuocopolizia-26024637/\#: \{\}:text=In\%20totale \%20nel\%202020\%20erano,sono\%20state $\% 2010 \% 20$ quelle $\% 20$ recuperabili (accessed on 28 January 2021).

66. ATAC. Carta dei Servizi 2020. Available online: https://www.atac.roma.it/docs/default-source/pubblicazioni/carta-serviziroma_20209447080e09054edda8f94596f53204d1.pdf?sfvrsn=52a8aab3_12 (accessed on 28 May 2021).

67. Sgarra, V.; Di Mascio, P.; Corazza, M.V.; Musso, A. An application of ITS devices for powered two-wheelers safety analysis: The Rome case study. Adv. Transp. Stud. 2014, 33, 85-96.

68. Corazza, M.V.; Musso, A.; Finikopoulos, K.; Sgarra, V. An analysis on health care costs due to accidents involving powered two wheelers to increase road safety. Transp. Res. Procedia 2016, 14, 323-332. [CrossRef]

69. Corazza, M.V.; Di Mascio, P.; Moretti, L. Management of sidewalk maintenance to improve walking comfort for senior citizens WIT Trans. Built Environ. 2017, 176, 195-206.

70. Corazza, M.V.; Musso, A. Urban transport policies in the time of pandemic, and after: An ARDUOUS research agenda. Trans. Pol. 2021, 103, 31-44. [CrossRef]

71. Musso, A.; Corazza, M.V. Improving Urban Mobility Management: The Rome Case. Trans. Res. Rec. 2006, 1956, 52-59. [CrossRef]

72. Musso, A.; Corazza, M.V.; Tozzi, M. Car Sharing in Rome: A Case Study to Support Sustainable Mobility. Procedia Soc. Behav. Sci. 2012, 48, 3482-3491. [CrossRef]

73. ISTAT. GeoDemo, I.stat. Available online: Demo.istat.it/popres/index2.php?anno=2019\&lingua=ita (accessed on 19 July 2021).

74. ACI. Open Parco Veicoli. Available online: http://www.opv.aci.it/WEBDMCircolante/ (accessed on 19 July 2021).

75. Deloitte. The Deloitte City Mobility Index. Available online: https://www2.deloitte.com/xe/en/insights/focus/future-ofmobility / deloitte-urban-mobility-index-for-cities.html (accessed on 21 June 2021).

76. TomTom. TomTom Traffic Index. Available online: https://www.tomtom.com/en_gb/traffic-index/ (accessed on 21 June 2021).

77. European Commission. GHSL_Global Human Settlement Layer. Available online: https://ghsl.jrc.ec.europa.eu/ucdb201 8visual.php\# (accessed on 21 June 2021).

78. Comune di Roma, Roma Mobilità. Covid 19: Impatto sulla mobilità 2020. Available online: https://romamobilita.it/it/covid-19 -impatto-sulla-mobilita (accessed on 15 May 2021).

79. Samira, R.; Pizzo, B.; Deakin, E. An integrated assessment of factors affecting modal choice: Towards a better understanding of the causal effects of built environment. Transportation 2018, 45, 1351-1387.

80. Musso, A.; Corazza, M.V. Visioning the bus system of the future: Stakeholders' perspective. Trans. Res. Rec. 2015, $2533,109-117$. [CrossRef]

81. Maxwell, J.A. Qualitative Research Design: An Interactive Approach; Sage: Los Angeles, CA, USA, 2002; pp. 87-105.

82. Matyas, M.; Kamargianni, M. The potential of mobility as a service bundles as a mobility management tool. Transportation 2019, 46, 1951-1968. [CrossRef]

83. Ratilainen, H. Mobility-as-a-Service: Exploring Consumer Preferences for MaaS Subscription Packages Using a Stated Choice Experiment. Master's Thesis, Delft University of Technology, Delft, The Netherlands, 31 August 2017.

84. Guidon, S.; Wicki, M.; Bernauer, T.; Axhausen, K. Transportation service bundling-For whose benefit? Consumer valuation of pure bundling in the passenger transportation market. Transp. Res. Part A Policy Pract. 2020, 131, 91-106. [CrossRef]

85. González Alonso, M.; van Oort, N.; Cats, O.; Hoogendoorn, S. Urban Demand Responsive Transport in the Mobility as a Service Ecosystem: Its Role and Potential Market Share. In Proceedings of the International Conference Series on Competition and Ownership in Land Passenger Transport-2017, Thredbo 15, Stockholm, Sweden, 12-15 August 2017.

86. Ho, C.; Hensher, D.; Mulley, C.; Wong, Y. Prospects for switching out of conventional transport services to mobility as a service subscription plans-A stated choice study. In Proceedings of the International Conference Series on Competition and Ownership in Land Passenger Transport-2017, Thredbo 15, Stockholm, Sweden, 12-15 August 2017.

87. Osterwalder, A.; Pigneur, Y.; Clark, T. Business Model Generation: A Handbook for Visionaries, Game Changers, and Challengers; Wiley and Sons: Hoboken, NJ, USA, 2010.

88. Smith, G.; Sochor, J.; Karlsson, I.M.C. Mobility as a Service: Development scenarios and implications for public transport. Res. Transp. Econ. 2018, 69, 592-599. [CrossRef]

89. Eckhardt, J.; Lauhkonen, A.; Aapaoja, A. Impact assessment of rural PPP MaaS pilots. Eur. Transp. Res. Rev. 2020, 12, 49. [CrossRef]

90. Hoadley, S. Mobility as a Service: Implications for Urban and Regional Transport. Discussion paper: Offering the Perspective of Polis Member Cities and Regions on Mobility as a Service (MaaS). Polis Traffic Efficiency and Mobility Working Group, Technical Report; Polis: Brussels, Belgium, 2017. 
91. ISFORT. $16^{\circ}$ Rapporto Sulla Mobilità Degli Italiani 2019. Available online: https://www.isfort.it/wp-content/uploads/2019/12/ 16_Rapporto_Audimob.pdf (accessed on 6 December 2020).

92. Agenzia per il Controllo e la Qualità dei Servizi Locali di Roma Capitale. Il Trasporto Pubblico a Roma. 2019. Available online: https:/ / www.agenzia.roma.it/it-schede-245-focus \%5C_sul\%5C_trasporto\%5C_pubblico \%5C_locale\%5C_luglio \%5C_ 2019 (accessed on 6 December 2020).

93. Sochor, J.; Karlsson, I.M.C.; Strömberg, H. Trying out Mobility as a Service: Experiences from a Field Trial and Implications for Understanding Demand. Trans. Res. Rec. 2016, 2542, 57-64. [CrossRef]

94. Tsouros, I.; Tsirimpa, A.; Pagoni, I.; Polydoropoulou, A. MaaS users: Who they are and how much they are willing-to-pay. Transp. Res. Part A Policy Pract. 2021, 148, 470-480. [CrossRef]

95. Pangbourne, M.; Mladenović, N.; Stead, D.; Milakis, D. Questioning mobility as a service: Unanticipated implications for society and governance. Transp. Res. Part A Policy Pract. 2020, 131, 35-49. [CrossRef]

96. Pangbourne, K.; Stead, D.; Mladenovic, M.; Milakis, D. The case of Mobility as a Service: A critical reflection on challenges for urban transport and mobility governance. In Governance of the Smart Mobility Transition; Marsden, G., Reardon, L., Eds.; Emerald Publishing: Bingley, UK, 2018; pp. 33-48.

97. Comune di Roma, Piano Roma Smart City. 2021. Available online: https://www.comune.roma.it/eventi/it/roma-innovationsmart-city.page (accessed on 19 July 2021). 